\title{
Integração regional e mudanças no estado de bem-estar \\ reflexões sobre a União Europeia e o Mercosul
}

\author{
Lucia Cortes da Costa
}

\section{SciELO Books / SciELO Livros / SciELO Libros}

COSTA, L. C. Integração regional e mudanças no estado de bem-estar: reflexões sobre a União Europeia e o Mercosul. In: COSTA, L. C., NOGUEIRA, V. M. R., and SILVA, V. R., orgs. A política social na América do Sul: perspectivas e desafios no século XXI [online]. Ponta Grossa: Editora UEPG, 2013, pp. 61-98. ISBN 978-85-7798-231-8. Available from: doi: 10.7476/9788577982318.0004. Also available in ePUB from: http://books.scielo.org/id/rfv9p/epub/costa-9788577982318.epub.

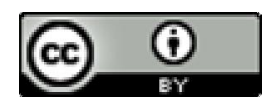

All the contents of this work, except where otherwise noted, is licensed under a Creative Commons Attribution 4.0 International license.

Todo o conteúdo deste trabalho, exceto quando houver ressalva, é publicado sob a licença Creative Commons Atribição 4.0.

Todo el contenido de esta obra, excepto donde se indique lo contrario, está bajo licencia de la licencia Creative Commons Reconocimento 4.0. 


\section{Integração regional e mudanças no estado de bem-estar: reflexões sobre a União Europeia e o Mercosul \\ Lucia Cortes da Costa}

\section{Introdução}

Vivemos numa época de transformações sociais, com um elevado grau de interdependência econômica e política entre os países. Nossa reflexão nesse capítulo parte da premissa de que as mudanças geopolíticas, econômicas e sociais têm impactos sobre a proteção social, no entanto, há particularidades desse impacto nos diferentes países. A internacionalização da economia favoreceu o deslocamento dos investimentos e a criação de espaços decisórios regionais, com a organização dos países em blocos, deu origem a outro arranjo político. O novo padrão tecnológico aliado a uma ofensiva política conservadora alterou o mercado de trabalho, elevou o desemprego e reduziu os direitos laborais, com impactos no sistema de proteção social. As mudanças demográficas, devido ao envelhecimento populacional e a redefinição nas relações familiares colocam novas demandas sociais. Pode-se afirmar que no século XXI, há novos e velhos desafios para o sistema de proteção social construído no século XX. Nesse contexto, ganha destaque o tema das reformas no estado de bem-estar nos países da Europa e amplia-se o debate sobre a proteção social nos países do Mercosul.

A União Europeia é a experiência mais consolidada de formação de bloco regional, cujo processo teve início com o Tratado de Roma, na década de 1950 e, depois, com o Tratado de Maastricht em 1992. O Mercosul, articulado na década de 1980, teve sua formalização com o Tratado de Assunção em 1991 e com o Protocolo de Ouro Preto, em 1994. Esses são fenômenos recentes na história do capitalismo ocidental e ainda não se tem dados consolidados sobre os impactos do processo de integração regional nas diferentes sociedades nacionais e nos sistemas de proteção social.

As mudanças geopolíticas e econômicas intensificaram-se a partir da década de 1990, como desmonte do bloco comunista soviético e a hegemonia norte-americana, a ascensão econômica da China, que ao lado da Índia e Rússia, passaram a ganhar destaque na economia mundial. Como uma reação a essas mudanças, os países europeus aprofundaram a sua integração formando 


\section{Lucia Cortes da Costa}

a Comunidade Europeia e quatro países ${ }^{1}$ da América do Sul formalizam o Mercosul, o qual adquiriu personalidade jurídica internacional. Os países periféricos enfrentaram novos desafios diante do alargamento da lógica de mercado, pois a maior concorrência elevou os riscos de isolamento das regiões menos desenvolvidas, como é o caso da América do Sul. A internacionalização da produção, do consumo e do capital financeiro, fragilizou os instrumentos de controle do Estado sobre o mercado. A abertura econômica afetou o nível de empregos e a proteção ao trabalho nos países em desenvolvimento. Nesse contexto, difundiram-se as ideias neoliberais e setores conservadores passaram a pressionar os governos para promoverem reformas no Estado, com o objetivo de reduzir os gastos públicos na proteção social e ampliar a liberdade de mercado.

Após a hegemonia neoliberal, a primeira década do século XXI foi marcada pelas crises econômicas, colocando novamente o debate sobre o papel do Estado na regulação do mercado. Nessa conjuntura histórica, os impactos no estado de bem-estar decorrem de múltiplos fatores, tais como: das crises econômicas, da capacidade de organização política das classes trabalhadoras, das mudanças demográficas e também das mudanças nas relações familiares. Há novos desafios para a proteção social pública num contexto de economia aberta, com elevado grau de concorrência entre os países e, no caso da Comunidade Europeia, com processo de integração regional que permite a mobilidade de trabalhadores, envelhecimento populacional e baixo crescimento econômico. Na América do Sul, os elevados níveis de desigualdade social, as históricas demandas de proteção para crianças e jovens convivem com o já evidente envelhecimento da população em alguns países, o que indica as dificuldades para construir um estado de bem-estar na região.

Nesse cenário do início do século XXI, de conflitos e transformações, um dos pontos no debate político atual é sobre o papel do Estado, do mercado e da família para assegurar proteção social. O estado de bem-estar construído no pós-segunda guerra mundial, a partir do pacto fordista-keynesiano, é alvo de críticas. $\mathrm{O}$ alargamento da lógica mercantil favorece a privatização de setores ligados aos serviços públicos e promove mudanças nas políticas de proteção social. Apresentam-se a seguir, alguns pontos do debate sobre a proteção social na Europa, a integração regional e as mudanças no estado de bem-estar. Buscam-se elementos para refletir sobre os países do Mercosul e a possibilidade de construir uma agenda social regional. Embora se reconheça que não é possível transpor modelos de integração e nem de bem-estar em razão das diferenças estruturais, econômicas, políticas e culturais entre os países da Europa e da América do Sul, é possível aprender com a experiência vivenciada naquela região.

1 Brasil, Argentina, Uruguai e Paraguai. 
Nesse capítulo, apresentamos algumas ideias sobre a integração regional, tendo como referência a União Europeia e o Mercosul, as mudanças que afetam o Estado e o sistema de proteção social. A pesquisa, que deu origem ao texto, tem um caráter exploratório, a partir de revisão da bibliografia levanta pontos para o debate, até mesmo porque a integração regional é um processo em curso do qual ainda não se tem dados conclusivos.

O texto a seguir está organizado em quatro itens, além dessa introdução. Primeiro, abordamos o Estado nacional, o conceito de soberania e integração regional; segundo, as possíveis implicações entre integração regional e proteção social; terceiro, o debate sobre as mudanças no estado de bem-estar; quarto comentários acerca da relação entre integração regional e proteção social no Mercosul.

\section{Os modelos de integração e a questão da soberania nacional}

O Estado nacional é um fenômeno histórico-político que teve início na Europa a partir do final do período medieval, mas consolidou-se no século XIX sob a forma de organização de um poder soberano que vincula uma população a um território, com laços de solidariedade e de obrigações jurídicas. O ponto central dessa forma de organização da sociedade ocidental esteve na ideia de soberania ${ }^{2}$, concebida como o poder absoluto, independente e reconhecido por todos, efeito erga omnes. A soberania externa ilimitada, com a tese de que todos os estados tem igual poder, fez de cada estado nacional um sujeito de direitos na ordem internacional. A ordem mundial foi então concebida como sendo formada por estados soberanos, com poderes ilimitados. Essa ideia de soberania nunca foi uma realidade fática para a maioria dos estados, especialmente para aqueles que se formaram depois do longo processo de descolonização na América Latina.

O poder entre os estados nunca foi igualitário e as relações políticas internacionais foram e são marcadas por conflitos. Com as mudanças na interpretação ${ }^{3}$ sobre a vinculação da legislação nacional ao Direito Internacional, renovou-se o questionamento sobre os limites da soberania externa e, no século XX, ampliaram-se as limitações da soberania interna com o Estado democrático de direito ${ }^{4}$, os poderes do estado foram colocados no limite da lei.

\footnotetext{
2 Ver a respeito a análise de Luigi Ferrajoli. Derechos y garantias: la ley del más débil. Madrid, Trotta, 2006.

3 Ver o debate entre as teorias do Direito, a doutrina monista (Kelsen) e a dualista (Triepel; Anziolotti).

4 O debate sobre os limites do poder do estado aflora no século XVII, com a polêmica entre as teses do absolutismo de Thomas Hobbes e o liberalismo de John Locke. No entanto, somente no final do
} 
A soberania passou a ser o poder do Estado dentro dos limites da lei ${ }^{5}$, com respeito às determinações do ordenamento jurídico nacional e das normas do direito internacional.

A trajetória histórica dos estados soberanos no mundo ocidental deu-se em meio a conflitos e guerras ${ }^{6}$. No século XX, após as duas guerras mundiais, houve mudança no conceito de soberania. Surgiu um novo consenso político que ampliou os espaços supranacionais e o poder das normas internacionais, especialmente a Declaração de Direitos Humanos de 1948 e a criação da Organização das Nações Unidas - ONU, 1945, e de outras instituições de caráter econômico, como o Banco Mundial, o Fundo Monetário Internacional. Em 1998, foi criado o Tribunal Penal Internacional, cuja vigência se deu a partir de 2002. A intenção de conter a soberania externa, como poder ilimitado, não se dá sem conflitos, pois nem todos os estados têm o mesmo poder na esfera internacional. Há um sistema desigual de poder entre os estados e há a ausência de instituições democráticas na ordem internacional, bem como, não existe a atuação de um poder cogente legítimo. Dessa forma, os estados buscam estratégias para consolidar suas posições econômicas e políticas na ordem mundial, sendo uma dessas estratégias, o processo de integração regional.

Na Europa, a política de integração, iniciada na década de 1950 com o Tratado de Roma, foi conduzida com o objetivo de elevar a competitividade da economia e alavancar um processo de desenvolvimento regional. $\mathrm{Na}$ década de 1990, essa opção política resultou no fortalecimento do bloco regional ${ }^{7}$, com a formação da União Europeia através do Tratado de Maastricht, assinado em 1992, que criou a moeda comum - Euro e o Banco Central Europeu.

Ganham destaque as esferas de decisões supranacionais na Europa, surgem novas instituições ${ }^{8}$, tais como a Comissão Europeia, Conselho Europeu,

século XIX, as classes trabalhadoras conquistam direitos políticos e inicia-se o Estado Democrático, o qual conviveu com períodos autoritários já no início do século XX. As crises econômicas e políticas do século XX levaram ao fascismo e nazismo na Europa e, na América Latina, aos governos ditatoriais.

5 No entanto, há a persistente discussão sobre o estado de exceção. Conforme AGAMBEN, Giorgio. Estado de exceção. São Paulo: Boitempo, 2004. ZOLO, Danilo. La justicia de los vencedores: de Nuremberg a Bagdad. Buenos Aires: Edhasa, 2007.

6 Ver HOBSBAWM, Eric J. Globalização, democracia e terrorismo. São Paulo: Companhia das Letras, 2007.

7 Deve-se considerar o desafio da unificação da Alemanha após o desmonte do bloco socialista.

8 Comissão Europeia: representa o conjunto dos membros, elabora propostas de nova legislação, tem o Direito de Iniciativa, assegura a vigilância sobre o cumprimento da legislação. Conselho Europeu: elege o Presidente da Comissão Europeia. Formado pelos chefes de Estado ou de governo de cada país da União Europeia, funcionou de maneira informal desde 1974, foi formalizado em 
Conselho da União Europeia e o Parlamento Europeu, que representam certos limites aos Estados nacionais, redefinindo o conceito de soberania. Progressivamente, foram alargados os campos de atuação das instituições supranacionais, redefinindo o papel dos Estados, sem, no entanto, eliminá-los. O debate sobre o impacto da integração regional nos Estados ainda é intenso, ocorre num contexto de ampliação da internacionalização da economia e de crises que afetam os países da Europa. As análises sobre o modelo de integração europeu podem ser organizadas em dois grupos, os teóricos que defendem a preservação da soberania dos Estados, numa versão intergovernamentalista da integração e, numa aposta no modelo supranacional, os teóricos que defendem um novo conceito de soberania coordenada.

O regionalismo ganhou força com a formação da União Europeia, afetando os Estados em razão da maior interdependência econômica e política dos países do bloco. Ainda não há consenso sobre as teorias que explicam esse processo de integração e sobre o impacto causado nas sociedades nacionais. Conforme Philippe C. Schmitter ${ }^{9}$, a teoria neofuncionalista destaca o papel dos atores regionais em detrimento dos Estados nacionais.

Os Estados membros, que colocam os termos do acordo inicial, continuam como atores importantes no processo, mas não determinam exclusivamente a direção e o alcance da mudança subsequente. Ao contrário, são os burocratas regionais, aliados a um conjunto cambiante de interesses auto-organizados e paixões, que buscam explorar os inevitáveis "transbordamentos" e "consequências não previstas" que ocorrem quando os Estados concordam em delegar certo grau de responsabilidade supranacional para realizar uma tarefa limitada; assim, descobrem que satisfazer tal função tem efeitos externos sobre outras de suas atividades interdependentes. (SCHMITTER, 2010, p.12).

1992 e tornou-se instituição formal em 2009. Tem como função estabelecer os rumos e prioridades políticas, não tem competência para aprovar legislação. Coordena políticas, firma Acordos. Conselho da União Europeia: conselho de Ministros dos países-membros. Coordena políticas de cada setor, aprova legislação em igualdade de condições que o Parlamento, Câmara legislativa colegiada. Toma decisões por unanimidade, regra geral, mas recentemente tem sido adotado o método de voto da maioria qualificada. Parlamento Europeu: Eleito por voto dos cidadãos europeus, a cada 5 anos, com a função de debater e aprovar legislação, atua junto com o Conselho no controle das instituições da União Europeia. Ainda existe o Tribunal de Justiça Europeu, que interpreta o Direito da União Europeia e resolve conflitos legais; Tribunal de Contas, que audita as contas na União Europeia, o Banco Central Europeu e o Banco Europeu de Investimento.

Uma análise das diferentes esferas de poder é proposta por HOOGHE, Liesbet y MARKS, Gary, 2004.

9 SCHMITTER, Philippe C. A experiência da integração europeia e seu potencial para a integração regional. Lua Nova, São Paulo, v.80, p.9-44, 2010. 
Há divergências teóricas ${ }^{10}$ no debate sobre a relação entre os Estados na ordem internacional. A tese de que os Estados não querem abrir mão da sua soberania ${ }^{11}$, mas aceitam articular políticas que, em última análise, favoreçam seus interesses, aparecem nas proposições do intergovernamentalismo. O modelo intergovernamental busca preservar as decisões nacionais e assegura que toda votação é por consenso ou unanimidade, não pela regra de maioria. A perspectiva intergovernamental, conforme Schmitter (2010) ${ }^{12}$, é desenvolvida, em especial, pelos pesquisadores de Harvard, buscando explicar a formação dos blocos regionais.

A direção e o ritmo da integração regional serão determinados pela interação de Estados soberanos, que controlam não só o início do processo de integração, mas também todos seus estágios subsequentes. Que o processo se mova para frente ou para trás ou se estagne depende do cálculo dos interesses nacionais e do poder relativo que pode ser mobilizado em cada questão específica. Sob nenhuma circunstância, esse processo poderia transformar a natureza de seus Estados membros; seu propósito é fortalecê-los e não enfraquecê-los. (SCHMITTER, 2010, p.13).

Criar espaços de poder supranacionais interfere na soberania dos Estados e pode afetar a legitimidade dos governos, com custos políticos dentro de cada país. Ao dar maior destaque às decisões supranacionais, considerando a desigualdade econômica e de poder dos 27 diferentes Estados que compõe a União Europeia, os países em desvantagens econômicas podem ser subordinados às políticas regionais levando a um enfrentamento político com duas dimensões: uma relacionada ao desgaste dos espaços decisórios nacionais, o descrédito dos governantes e, outra, contra as pressões das decisões regionais,

\footnotetext{
10 Conforme Olsson (2007), podem ser identificadas três teorias que buscam explicar a existência da sociedade internacional, como um fenômeno distinto da existência dos Estados nacionais. A teoria realista cuja fonte pode ser encontrada em Thomas Hobbes, na qual há guerra de todos contra todos, nesse sentido, a sociedade internacional seria apenas uma arena e não uma verdadeira sociedade. A teoria racionalista, cuja inspiração remonta John Locke, na qual, há cooperação entre os Estados e o Direito Internacional formaliza os pactos que criam uma sociedade internacional. Teoria revolucionista, inspirada em Kant, na qual os Estados nacionais são momentos transitórios rumo a formação de uma sociedade cosmopolita, a paz mundial.

11 Conforme o debate pontuado por Luigi Ferrajoli. A soberania no mundo moderno: nascimento e crise do Estado nacional. São Paulo: Martins Fontes, 2002.

12 Para Schmitter, existem várias teorias que buscam explicar a integração europeia, mas elas podem ser agrupadas em dois conjuntos: a) ontológicas: que buscam analisar se há ou não transformações na natureza dos Estados nacionais; b) epistemiológicas: que buscam analisar as questões econômicas, políticas e culturais do processo de integração. $\mathrm{O}$ autor ainda ressalta as diferentes interpretações do institucionalismo, presente no debate sobre a União Europeia.
} 
fomentando o nacionalismo ${ }^{13}$. Assim, o regionalismo é um campo aberto de conflitos e ainda não se tem uma avaliação mais consistente sobre seus efeitos na vida de cada sociedade nacional. Fala-se também de integração de duas velocidades $^{14}$, tanto no caso da União Europeia como no Mercosul. Estados com economias mais consolidadas têm maior sucesso na integração, enquanto outros Estados, com maiores dificuldades, teriam um tempo mais lento para ajustarem-se ao processo de integração.

Entre as teorias intergovernamental e supranacional, coloca-se a perspectiva da governança multinível, dando uma interpretação para a complexidade das relações que envolvem as diferentes esferas de poder nacional, subnacional e supranacional.

El modelo de gobernanza multinivel (GML) rechaza la separación entre las políticas interna e internacional, presupuesto del modelo estatocéntrico. Los Estados son una parte integrante y potente de la EU, pero ya no constituyen el único interfaz entre las arenas supra y subnacionales. Asimismo, los Estados comparten, más que monopolizan, el control sobre muchas actividades que ocurren dentro de sus respectivos territórios. (HOOGHE; MARKS, 2004, p.56).

O processo de integração regional cria nova dinâmica entre os Estados, envolve também os segmentos organizados de cada sociedade nacional. A forma de relacionamento das diferentes esferas (nacionais, subnacionais e supranacionais) alarga o espaço de construção política. Nesse sentido, o poder e a forma de organização dos diferentes atores, em cada Estado nacional, pode dar um novo colorido ao processo de integração, fazendo avançar ou recuar as pressões internas e externas.

Menz (2005) aborda o processo de integração europeia (europeanization) considerando as diferentes capacidades de respostas dos atores em cada Estado e contexto político nacional. Dessa forma, refuta a tese de que há apenas um processo induzido de fora, da União Europeia, para afetar os Estados, e considera que há também diferentes respostas surgidas nos diferentes tipos de capitalismo (Alemão - capitalismo organizado e Anglo-americano, capitalismo liberal desorganizado). Menz (2005) aponta

\footnotetext{
13 Deve-se considerar ainda que há movimentos separatistas dentro dos Estados, como exemplos: na Espanha, na região da Catalúnia, existem grupos que buscam a independência diante do governo central de Madri. No Reino Unido, a luta política da Irlanda do Norte contra o governo em Londres.

14 Na discussão sobre o Mercosul, ver o Texto para Discussão do IPEA, no 1131, de 2005. GIAMBIAGI, Fábio; BARENBOIM, Igor. MERCOSUL: por uma nova estratégia brasileira. No caso da União Europeia, vários autores, entre outros, MENZ, G. Europeanisation meets Organized Capitalism. Oxford, 2005.
} 


\section{Lucia Cortes da Costa}

que houve uma pressão liberalizante da União Europeia, um desequilíbrio de poder entre os representantes do capital e do trabalho, com perda de poder para os últimos, mas não concorda que em todas as sociedades nacionais, as respostas a essa pressão tenham sido as mesmas. A partir dessa análise, é preciso destacar a importância de considerar a dinâmica entre as diferentes esferas de poder ${ }^{15} \mathrm{e}$ a capacidade de respostas dos Estados nacionais, especialmente a pressão de setores organizados que sejam capazes de limitar as pressões externas. Menz (2005) coloca a tese da re-regulação do capitalismo e aponta que há diferentes respostas. A "europeanisation" também pode ser condicionada por iniciativas nacionais.

Diferente da União Europeia, o Mercosul tem um caráter intergovernamental, as decisões são tomadas por consenso e ainda não existem instituições supranacionais na região. O caráter intergovernamental do Mercosul pode ser explicado, entre outras razões, pela tradição política da região, com modelo presidencialista e governo ocupado por líderes carismáticos, pelo populismo. O passado de rivalidades e desconfianças entre os países da região enfraquece as propostas supranacionais e reforça o intergovernamentalismo. As decisões do Mercosul só entram em vigor após cada Estado membro ${ }^{16}$ aprovar internamente, via parlamento nacional, e depositar o documento decisório na Secretaria do Mercosul. Esse processo é demorado porque exige a unanimidade. Como exemplo, podemos ver o trâmite do Acordo Multilateral de Seguridade Social, aprovado em 1997 no Mercosul e que só entrou em vigor em 2005, depois que o Paraguai também concordou assinando o referido Acordo.

$\mathrm{O}$ aspecto institucional do Mercosul ainda carece de desenvolvimento, também é preciso tornar mais democráticas as relações com a sociedade civil, ampliar o espaço de participação de diferentes atores dos diversos Estados. A criação do Fórum Consultivo Econômico e Social - FCES ${ }^{17}$ já foi um avanço, mas ainda não tem uma sistemática de trabalho que torne mais efetiva a participação de sindicatos, empresários e segmentos da sociedade civil nos processos decisórios. É um espaço consultivo e com dificuldades para pautar o debate no bloco. A articulação dos segmentos organizados ${ }^{18}$

\footnotetext{
15 Conforme assinalam Hooghe; Marks (2004).

16 Os Estados membros de pleno direito são: Brasil, Argentina, Uruguai e Paraguai e recentemente foi aprovada a inclusão da Venezuela. Como membros associados, Bolívia, Chile, Colômbia, Equador e Peru. Ver dados no site oficial: <http://www.mercosur.int>

17 Fórum Consultivo Econômico e Social (FCES), de caráter regional e com seções nacionais, espaço em que há presença de empresários, trabalhadores, segmentos da sociedade civil e consumidores.

18 O campo sindical registra a atuação da Coordenadora de Centrais Sindicais do Cone Sul (CCSCS), composta da CGT e CTA (Argentina), CUT, CGT e Força Sindical (Brasil), CUT (Chile), CUT (Paraguai), PIT/CNT (Uruguai).
} 
de cada sociedade nacional no espaço do Mercosul ainda é frágil, apesar de serem registrados avanços com a realização das Cúpulas Sociais e do fortalecimento de iniciativas, tais como o grupo "Somos Mercosul19". Os grupos de trabalho do Mercosul $^{20}$ articulam temas variados e com participação de setores da sociedade civil, mas sem o poder de decisão, são grupos consultivos e de pressão. Ainda não há um debate dentro de cada sociedade nacional sobre as vantagens ou riscos da integração. No Brasil, ainda há resistências à ideia de integração e desconfiança que barra a construção de instituições supranacionais, conforme análise de Vigevani e Ramanzini Jr. (2009, p.12). "Em parte da sociedade brasileira, há um interesse reduzido e, em alguns casos, abertamente contrário ao Mercosul e ao seu possível aprofundamento".

O Parlamento do Mercosul, criado em 6 de dezembro de 2006, ainda não conta com o voto direto dos cidadãos dos Estados membros, exceto o Paraguai que já realizou eleições diretas, os demais Estados continuam com a eleição via voto dos parlamentares nacionais ${ }^{21}$. O Conselho Mercado Comum - CMC é o órgão superior, responsável pela condução política do processo de integração, composto pelos Ministros das Relações Exteriores e de Economia dos quatro países, não tem poder vinculante para as decisões que possam interferir em aspectos da legislação dos países do bloco sem a aprovação de cada Estado membro. O Grupo Mercado Comum, o órgão executor do Mercosul, tem sua atuação definida pelas decisões aprovadas pelo CMC, que são por unanimidade dos Estados membros.

Pode-se afirmar que a perspectiva intergovernamental do Mercosul expressa a falta de confiança mútua entre os seus membros e uma posição ambígua em relação aos objetivos da integração, na qual, cada Estado busca maiores ganhos sem perder nenhum poder de negociar fora do bloco ou de ceder para instituições supranacionais a coordenação das políticas econômicas

\footnotetext{
19 SOMOS MERCOSUL é uma iniciativa pública, lançada pela Presidência Pro Tempore do Uruguai no bloco em 2005, com o apoio da FESUR, que tem por objetivo envolver a cidadania no processo da integração regional, gerando novos espaços para que a sociedade civil e os governos locais possam debater, formular demandas e participar dos processos decisórios. Disponível em: <http:// www.somosmercosur.net/portugues>. Acesso em: 3 dez. 2011.
}

20 Subgrupos de Trabalho: (SGT-1) Comunicações; (SGT-2). Aspectos Institucionais; (SGT3) Regulamentos Técnicos e Avaliação da Conformidade; (SGT-4) Assuntos Financeiros; (SGT-5) Transportes; (SGT-6) Meio Ambiente; (SGT-7) Indústria; (SGT-8) Agricultura; (SGT-9) Energia e mineração; (SGT-10) Assuntos Trabalhistas, Emprego e Seguridade Social; (SGT-11) Saúde; (SGT12) Investimentos; (SGT-13) Comércio Eletrônico; e (SGT-14) Acompanhamento da Conjuntura Econômica e Comercial. Disponível em: < http://www.camara.gov.br/mercosul/blocos/mercosul. htm>. Acesso em: 6 dez. 2011.

21 O Protocolo Constitutivo do Parlamento do Mercosul prevê no artigo $6^{\circ}$ as eleições diretas para seus parlamentares. 


\section{Lucia Cortes da Costa}

e fiscais. Outro aspecto que difere da União Europeia é a política monetária, a zona do Euro condiciona a política fiscal e monetária dos países ${ }^{22}$. No Mercosul, não há moeda comum, embora o governo Lula (2006) tenha ressaltado a intenção de se criá-la. O intergovernamentalismo é uma aposta liberal de pensar nos interesses, capacidade de concorrência de cada economia nacional, com baixa coordenação de políticas comuns. A formação de um mercado comum exigirá maiores esforços para construir as instituições necessárias ao processo de integração.

\section{Integração regional e proteção social}

Um desafio que parece emergir no contexto atual é o de manter a união dos Estados, formando de fato uma Comunidade Europeia, num contexto de crise econômica com alto custo político para as decisões sobre os ajustes nos gastos públicos que reduzem a proteção social.

La reducción del déficit del Estado, exigida para alcanzar la unidad monetaria, se consiguió en España (durante el periodo 1993-2004) a base de reducir el gasto público social por habitante en términos absolutos durante los años 1993-1995, y en términos relativos a partir de 1996. (NAVARRO, 2010) ${ }^{23}$.

$\mathrm{Na}$ década de $1970^{24}$, com a crise econômica que afetou também os países desenvolvidos, especialmente o rompimento do padrão ouro e da neutralidade da política monetária dos Estados Unidos, surge o questionamento sobre o papel do Estado e sua capacidade para promover o desenvolvimento. A Europa viveu um processo de mudanças políticas com clara fragilização dos partidos trabalhistas de inspiração socialista, o que favoreceu a adoção de medidas liberais por alguns Estados, com restrições aos gastos sociais,

\footnotetext{
22 Nem todos os países da União Europeia estão na zona do Euro, como a Inglaterra que mantém sua moeda.

23 NAVARRO. V. ¿Quién paga los costes del euro? Disponível em: <http://www.vnavarro. org/wp-content/uploads/2010/02/quien-paga-los-costes-del-euro-18feb10.pdf>. Acesso em: 10 set 2011 .

24 Os conflitos na esfera internacional ficaram evidentes na Assembleia Especial das Nações Unidas, em 1974, em que se aprovou a nova Ordem Econômica Mundial, buscando dar um tratamento mais favorável aos países em desenvolvimento. A organização política dos países em desenvolvimento ficou conhecida como o Grupo dos 77 , pedindo mudanças nas regras do comércio mundial. No mesmo contexto, as crises do petróleo em 1974 e 1979 afetaram as relações internacionais, favorecendo o surgimento de teses conservadoras de inspiração liberal nos governos de Margareth Thatcher na Inglaterra e de Ronald Reagan nos Estados Unidos. Ponto central desse contexto foi o rompimento do acordo de Bretton Woods (COSTA, 2006).
} 
objetivando assegurar a estabilidade monetária. O neoliberalismo esteve na pauta dos debates políticos e acadêmicos nos países desenvolvidos nas décadas de 1970 e 1980. O modelo de capitalismo anglo-americano ganhou destaque com a força das reformas liberais de Margaret Thatcher e Ronald Reagan, especialmente na questão laboral.

$\mathrm{Na}$ América do Sul, surgiu, na década de 1980, por decisão política dos governos do Brasil e da Argentina, a proposta de integração regional que resultou no Mercosul, através do Tratado de Assunção em 1991, envolvendo também Paraguai e Uruguai. O processo de integração através do Mercosul surge como uma estratégia defensiva frente aos riscos de isolamento da economia da região dentro de uma ordem mundial mais competitiva. $\mathrm{O}$ foco inicial do Mercosul era elevar o comércio na região, liberalizar a economia, com objetivos mais imediatos, a integração com construção de aspectos institucionais para coordenar políticas de longo prazo não era prioridade.

O contexto ideológico da década de 1990, na América Latina, foi de divulgação e acolhimento da ideologia neoliberal, favorecendo teses conservadoras que buscavam justificar uma redução do papel do Estado na área da proteção social. Esse contexto foi sintetizado nas proposições do "Consenso de Washington", com recomendações de ajustes fiscais para sanear a economia dos países em desenvolvimento. O ponto central das teses neoliberais era elevar a competitividade da economia e promover ajustes voltados para o mercado. Não se colocou na agenda política a preocupação com padrões igualitários na sociedade. A atuação do Estado deveria ser apenas para os segmentos em situação de pobreza, via transferências de rendas que assegurem um mínimo de consumo e programas focalizados, e não para fomentar a igualdade social. A família foi valorizada como espaço protetivo, colocando a proteção social pública como subsidiária nos casos de maiores riscos e pobreza. Houve ainda uma valorização das iniciativas da sociedade civil na área social, com a valorização do trabalho voluntário e de organizações não governamentais.

A internacionalização da economia afetou o Estado forjando um campo de relações políticas que redefine a ideia de soberania nacional a partir da integração regional, evidente no caso da União Europeia. O Tratado de Maastricht ${ }^{25}$ estabelece um limite para a dívida pública nos países da zona do Euro em 3\% do PIB e controle da inflação, o que leva à necessidade de conter os gastos públicos em políticas sociais e limita políticas com objetivo de pleno emprego.

Após a crise financeira que abalou a economia mundial em 2008 e 2009, há uma retomada da discussão sobre o papel do Estado no desenvolvimento

25 O artigo 104 do Tratado de Maastricht coloca a possibilidade de multar os países cujos déficits extrapolem $3 \%$, sem as justificativas já definidas para situações imprevistas. 


\section{Lucia Cortes da Costa}

econômico e social na América do Sul. ${ }^{26}$ Há um ponto interessante nessa conjuntura, pois, enquanto na Europa cresceu as ideias conservadoras em defesa do mercado ${ }^{27}$ na década de 2000, nos países do Mercosul, os partidos de orientação de esquerda ascendem ao poder. Nesse sentido, verificam-se duas posturas distintas em relação ao papel do Estado. Na União Europeia, o capitalismo desorganizado (anglo-saxão) segue na crítica ao Estado e buscando reformas liberais, enquanto no Mercosul, há uma valorização do papel ativo do Estado no desenvolvimento. No entanto, esse debate registrado nos países da América do Sul não se configura num retorno aos ideais do intervencionismo e da planificação econômica focada na defesa dos interesses nacionais. O modelo de economia fechada e o protecionismo não se colocam como alternativas possíveis num contexto de maior interdependência entre os países.

A internacionalização da economia exige novas formas de coordenação das políticas públicas, o que favoreceu o discurso a favor da União Europeia, bem como a construção de estruturas institucionais supranacionais, mas ainda não é evidente no Mercosul, onde é necessário desenvolver os aspectos político-institucionais capazes de favorecer a coordenação das políticas econômicas, fiscais e sociais.

O atual contexto exige novas formas de atuação do Estado, considerando-se a relevância dos espaços de decisões políticas de organismos internacionais. A integração europeia coloca desafios na luta pelas transformações políticas $^{28}$. Atualmente, a perspectiva cosmopolita e supranacional não pode ser negada pelas forças políticas na Europa, levando a rever a política nacional e a tese do reformismo democrático, especialmente depois da crise que assolou a Grécia, Espanha, Itália e Portugal. Há um nível de conflito social que pode afetar a legitimidade da integração e favorecer novos nacionalismos. O debate sobre as políticas sociais destaca-se no contexto de crise econômica em razão do desemprego. As teorias sobre a política social propõem diferentes interpretações sobre as funções e objetivos da proteção social e sua relação com os níveis de competitividade da economia.

$\mathrm{Na}$ visão estruturalista, a política social é um elemento necessário para o desenvolvimento econômico. As funções das políticas sociais, conforme Clauss Offe (1984), estão relacionadas ao assalariamento da força de trabalho

\footnotetext{
26 BOSCHI, Renato; GAITÁN, Flavio. Intervencionismo estatal e políticas de desenvolvimento na América latina. Caderno CRH, Salvador, v. 21, n. 53, p. 305-322, maio/ago. 2008.

27 Ver toda discussão sobre flexiseguridade e as medidas para flexibilizar o mercado de trabalho. ARTILES, Antonio Martín. Modelo social Europeo de bajo coste? Arxius de Ciencias Sociais, n.18, Juny, 08.

28 Ver Giuseppe Vacca (2009).
} 
e ao incentivo ao sistema de trocas dentro da sociedade de mercado. Sobre a tese de Claus Offe, de que a política social favorece o assalariamento da força de trabalho, há que se considerar as diversas formas de trabalho realizados na sociedade capitalista que, embora se vinculem à reprodução do capital, não estão sob a forma do assalariamento. Assim, seguindo a tese de Claus Offe, pode-se concluir que as políticas sociais têm resultados limitados, pois sobra um vasto contingente de trabalhadores fora do mercado laboral.

[...] al centrarse en la mercantilización de la fuerza de trabajo, reducen el concepto de trabajo al trabajo asalariado, dejando de lado el trabajo doméstico y reproductivo; y tampoco tienen en cuenta la heterogeneidad del trabajo, lo que les lleva a hacer generalizaciones dicotómicas del tipo de trabajo asalariado-capital, que limitan el análisis. ${ }^{29}$

As políticas sociais surgidas no período pós-guerra são analisadas como resultado do pacto fordista-keynesiano. A teoria de Keynes (1936) permite relacionar os gastos públicos ao aumento da demanda dentro da sociedade de mercado, favorecendo o crescimento econômico em época de crise (COSTA, 1999). O Estado, ao gerar gastos improdutivos, favoreceu a retomada dos investimentos ao elevar a demanda, numa busca de pleno emprego. Essa forma de atuação do Estado legitimou a ordem social e expandiu as políticas sociais, no período que ficou conhecido como época de ouro do capitalismo, conjugando crescimento econômico, elevação da produtividade do trabalho e aumento no padrão de consumo das classes trabalhadoras. Tal ciclo virtuoso do capitalismo perdeu força na década de 1970 e, do ponto de vista político, a teoria monetarista orientou a agenda dos governos com uma abordagem liberal das políticas sociais, reduzindo os gastos públicos, favorecendo o setor privado (lucrativo e filantrópico) na provisão de serviços sociais. A adoção de políticas keynesianas, num contexto de abertura econômica e integração regional, podem tornar ineficazes os gastos públicos para gerar empregos (COSTA, 2006). A política adotada por um Estado pode favorecer o crescimento de empregos em outro país, via aumento de importações para atender ao acréscimo da demanda e ainda, com a liberdade na circulação de trabalhadores, pode favorecer movimentação da mão de obra com menores salários ${ }^{30}$. De forma que são ineficazes, nesse contexto, os instrumentos de regulação pensados

29 José Adelantado, José Antonio Noguera y Xavier Rambla. Cambios en el estado del bienestar. Políticas sociales y desigualdades en Espana. Disponível em: <http://www.magpoliticasociales.cl/documentos/adelantado.pdf>. Acesso em: 20 ago. 2011.

30 MUÑOZ DE BUSTILLO, Rafael (2000), também aponta os limites de políticas keynesianas em economias abertas. 


\section{Lucia Cortes da Costa}

para modelos de economia fechada ou protegida, podendo agravar a crise ao elevar os gastos e dívida pública. Outro aspecto das políticas keynesianas é a necessidade de um pacto social, tipo fordista, com forte pressão de setores organizados da sociedade (sindicatos de trabalhadores e empregadores), o que não é fácil de articular num contexto de reduzido crescimento econômico e elevação de desemprego nos países do sul da Europa.

Fala-se numa crise de solidariedade dentro da classe trabalhadora ${ }^{31}$, em que setores das classes médias e altas não aceitam pagar mais impostos para financiar um sistema de proteção social de caráter universal, preferindo buscar no mercado mecanismos de seguro social na área da saúde, previdência e no sistema particular de educação. Dessa forma, há também um rompimento do pacto de solidariedade dentro da classe trabalhadora, cujo efeito é elevar a desigualdade dentro da sociedade, fazendo mais distantes os níveis de vida e consumo da base da pirâmide social e do topo. Assim, há uma tendência de privatizar a provisão de proteção e serviços sociais e ao mesmo tempo tornar a proteção pública voltada para atender segmentos mais pobres das classes trabalhadoras, com perda na qualidade dos serviços públicos e com critérios de acesso a benefícios mais restritivos.

A teoria dos regimes de bem-estar social, de Gosta Esping-Andersen (1991), compara a proteção social considerando a relação entre Estado, mercado e familia. Os regimes de proteção demonstram a maior ou menor participação do Estado no provimento do bem-estar, sendo o socialdemocrata (Suécia) aquele no qual o Estado tem maior atuação com políticas universais, o liberal (Estados Unidos) marcado pela maior participação do mercado e atuação residual do Estado. O conservador (Alemanha) revela uma atuação do Estado com base corporativa, para segmentos da classe trabalhadora em sistemas contributivos. Não é possível fazer uma separação rígida nos regimes de bem-estar. Em todos os casos, há sempre uma relação entre alguns programas de caráter universal, outros de caráter contributivo e outros focalizados e assistenciais. O que difere um regime de outro é a amplitude e foco de atuação da proteção social pública. A família segue como a base da proteção social privada que, num sistema capitalista, busca os meios para prover suas necessidades através da inserção no mercado de trabalho. Apesar das várias críticas que o autor tem recebido, especialmente dos movimentos feministas, sua análise passou a ser um parâmetro adotado para o estudo dos regimes de proteção social.

Num contexto de transformações nas esferas do Estado, do mercado e da família, cresce o debate sobre os regimes de proteção social e as reformas no estado de bem-estar.

31 ANTÓN, Antonio. Reestructuración del Estado de bienestar. Madrid: Talasa, 2009. 


\section{O estado de bem-estar em debate}

A proteção social envolve ações de diferentes esferas ${ }^{32}$, mas o que tornou esse tema relevante no século XX foi a ampliação da atuação do Estado na provisão de bens e serviços sociais, com garantias jurídicas como direitos dos cidadãos, ampliando o conceito de cidadania.

Conforme Singer (2003), os direitos sociais resultam da luta pelo reconhecimento na esfera pública dos interesses das classes trabalhadoras, em busca de conter a exploração capitalista e assegurar melhores níveis de vida. Dessa forma, para Singer (2003), são os membros das classes trabalhadoras ${ }^{33}$ os titulares dos direitos sociais. Uma vez reconhecidos esses direitos, ampliou-se a esfera de atuação do Estado, com a expansão da administração pública e do sistema tributário, necessários para o financiamento e execução das tarefas relacionadas às políticas sociais. Essa explicação vincula o estado de bem-estar às pressões dos trabalhadores organizados em sindicatos.

A atuação do Estado na garantia de acesso a bens e serviços fora do mercado consolidou-se na sociedade ocidental no século XX. Somente com a generalização do assalariamento da força de trabalho e com a ampliação das liberdades civis e políticas, o Estado passou a assumir compromissos frente às situações de riscos que envolvem os trabalhadores, especialmente a cobertura de riscos inerentes à perda da capacidade de trabalho ou impedimentos de participar do mercado de trabalho. Essa tese de ampliação da cidadania a partir da conquista de direitos nas esferas civil, política e social foi proposta por Mashall ${ }^{34}$ e esteve na base das análises sobre o estado de bem-estar. O que configura o estado de bem-estar nas sociedades europeias é conjugação da proteção social pública e de regimes democráticos. No entanto, deve-se registrar que a proteção social, via políticas sociais, também é registrada nos Estados autoritários ${ }^{35}$.

\footnotetext{
32 Conforme Esping-Andersen (2011), a proteção social realiza-se pela atuação das esferas privadas, mercado de trabalho e família, e da esfera pública, o Estado.

33 Deve-se reconhecer que a classe trabalhadora não é homogênea e que a proteção social não abarca todos os trabalhadores. Os segmentos mais organizados da classe trabalhadora, os operários industriais e os funcionários públicos foram mais protegidos pelas políticas keynesianas, os setores ligados à economia informal ou mais recentemente o setor de serviços, contam com níveis de proteção mais precários. Sempre há variações nos níveis de proteção dos trabalhadores conforme o poder político e capacidade de organização de suas instituições, especialmente os sindicatos.

34 MARSHALL, T. H. Cidadania, classe social e status. Rio de Janeiro: Zahar, 1967.

35 Como exemplo, pode-se analisar a expansão da previdência social no Brasil, realizada pelo governo militar num período de ditadura. Outro exemplo é a atuação na Alemanha e Itália, durante os governos nazista e fascista.
} 
A discussão atual sobre o estado de bem-estar na Europa destaca alguns pontos: a crise econômica e o desemprego, o custo político das reformas radicais, as mudanças sociais especialmente com a entrada das mulheres no mercado de trabalho, imigrantes e mudanças demográficas. A seguir, apresentamos aspectos desse debate sobre a crise do estado de bem-estar na Europa.

\section{O estado de bem-estar em situação de elevado desemprego}

A Europa foi o espaço onde se constituiu a proteção social a partir da atuação do estado de bem-estar, experiência que foi difundida para os países da América Latina ${ }^{36}$. O requisito essencial para o acesso aos bens e serviços proporcionados pelas políticas sociais foi o vínculo de cidadania, definido como a relação jurídica que liga o indivíduo à sociedade politicamente organizada, ao Estado nacional e à condição de emprego do trabalhador.

No regime conservador de bem-estar ${ }^{37}$, muitos direitos de proteção social são restritos aos trabalhadores com vínculo de emprego, tais como seguro desemprego, aposentadorias, auxílios acidentes e doenças profissionais. Tais benefícios são cobertos pelo sistema de proteção vinculado à contribuição dos trabalhadores a um fundo de solidariedade em regime de repartição. A empresa paga parte dessa contribuição em relação ao número de empregados e o Estado tem um aporte residual de recursos. Nesse sentido, há um mecanismo de distribuição horizontal da renda, a classe trabalhadora contribui para a seguridade social. O que se destaca é a manutenção do assalariamento e um compromisso forte dentro da própria classe trabalhadora, sem criar, necessariamente, uma distribuição vertical da riqueza. Esse mecanismo garantiu o pacto fordista-keynesiano com economias funcionando em pleno emprego.

O financiamento do estado de bem-estar está atrelado ao nível de contribuição dos trabalhadores, de forma que em situação de elevado desemprego, há redução na sua base de financiamento e, ao mesmo tempo, elevação das despesas devido ao pagamento de benefícios aos desempregados e às aposentadorias. Assim, em situações de crise com elevação de desemprego, o estado de bem-estar é questionado, as contribuições são colocadas como um empecilho à contratação de trabalhadores, já que custos reduzem a competitividade das empresas e retiram parte do salário dos empregados para pagar benefícios aos que ficam fora do mercado laboral. Em situação de

\footnotetext{
36 Ver Sônia Fleury (1994), análise sobre a proteção social na América Latina. Os países da América Latina não chegaram a construir um estado de bem-estar, mas sim, efetivar políticas sociais em contextos de governos autoritários e sem universalizar a proteção social pública.

37 Em regime conhecido como bismarckiano ou corporativo, focado na proteção do trabalho do homem, provedor da família, as mulheres foram tardiamente incluídas.
} 
desemprego estrutural, esse impasse do financiamento do estado de bem-estar torna-se mais problemático e aparece a crise do modelo de proteção baseado na solidariedade do pacto fordista.

Conforme Muñoz de Bustillo (2000), a ampliação do comércio internacional e de fluxos financeiros não é novidade, o que houve foi uma redução desse processo no período das guerras mundiais do século XX e depois a sua retomada foi anunciada na década de 1980, como globalização. Para o autor, a novidade não é a globalização, mas o contexto institucional no qual ela ocorre, o peso do Estado na economia. Hoje, para ativar o funcionamento de políticas keynesianas, é preciso a coordenação de políticas econômicas e monetárias dos diferentes países. Para isso, é necessário um desenho institucional que ainda não existe, nem na União Europeia. Quanto mais orientadas para o exterior as empresas, menor o apoio para as políticas de elevar a demanda nacional, porque elas podem afetar o custo de produção. Assim, há no debate atual a tese de que a maior abertura da economia e a ausência de mecanismos de coordenação de políticas econômicas e monetárias, a opção por câmbios quase fixos reduz a efetividade de políticas keynesianas e afeta o estado de bem-estar.

Há uma crítica comum dos setores conservadores e partidos liberais de que o estado de bem-estar eleva os custos do trabalho e afeta negativamente a competitividade exterior das empresas. Contrapondo-se a esse argumento, Muñoz de Bustillo (2000) afirma que ao não ter algumas despesas cobertas pelo estado de bem-estar, os salários tenderiam a ser mais altos e considerando ainda que os gastos sociais favorecem a elevação da produtividade, o seu financiamento não afeta negativamente a competitividade das empresas. $\mathrm{O}$ autor expõe ${ }^{38}$ que ao contrário do que se divulga, existe uma relação positiva entre o grau de abertura de um país ao exterior e o peso do setor público. Cita o trabalho de Rodrik (1997) afirmando que o gasto social diminui o risco de flutuações do consumo, legitimando a abertura econômica que evita protecionismo em situação de crise. A dificuldade é taxar o capital que tem mobilidade e pode migrar para lugares com menores custos fiscais. A internacionalização da economia afeta o trabalho, devido ao deslocamento de parte da produção para países com mão de obra menos qualificada e menor salário, o que afeta a capacidade de negociação dos trabalhadores.

Muñoz de Bustillo (2000) afirma que há na Europa três medidas de combate ao desemprego: mudança na legislação para reduzir custos laborais em setores de menor produtividade; desenvolvimento de novos setores intensivos em mão de obra e criação de políticas ativas de mercado de trabalho

38 Conforme análise de Muñoz de Bustillo (2000), especialmente nas páginas de 50 a 108. 


\section{Lucia Cortes da Costa}

- qualificação da mão de obra. O desemprego não é analisado a partir das questões estruturais do modelo de acumulação do capital, mas do ponto de vista da regulação do mercado de trabalho. Essa forma de atuar frente ao desemprego tem sido ineficaz para alterar os fatores que condicionam a baixa capacidade de gerar empregos na economia, na medida em que atua sobre as consequências e não sobre suas causas.

Para Antón (2009), existem três tendências na reestruturação do estado de bem estar na Europa: 1) separar classes altas e médias com sistemas privados de proteção; 2) reduzir gastos do Estado, voltados de forma assistencial para setores mais pobres e sem afetar distribuição vertical da renda; 3) colocar em situação defensiva as classes média e baixa, que sofrem com a contenção dos gastos públicos e deterioração dos serviços e não podem suportar os custos do sistema privado. Para o autor, um fato importante na análise sobre a reestruturação do estado de bem-estar é o rompimento da aliança entre segmentos da classe trabalhadora, em que as classes altas e médias assumem uma visão individualista da proteção social.

Com o crescimento do desemprego, o estado de bem-estar seria reestruturado num sentido não igualitário, mas focado em atender segmentos em riscos sociais mais graves e a população em situação de pobreza. Dessa forma, o Estado assumiria maior parte dos serviços assistenciais, especialmente programas de renda mínima ${ }^{39}$, custeados por impostos e não por contribuições, tendo como objetivo manter níveis mínimos de consumo para os setores mais vulneráveis. Essa reestruturação retira o objetivo de promover igualdade social, pois reafirma distintas formas de proteção social, mantendo a proteção pública para os pobres, com reduzida capacidade de distribuição vertical e horizontal da renda.

Como o processo de integração pode ter relação com essa reestruturação do estado de bem-estar? Como foi possível romper com o pacto de solidariedade da classe trabalhadora? Devemos lembrar que o mercado de trabalho é espaço de disputa e concorrência entre trabalhadores e, em situação de crise na qual a conquista de emprego em tempo integral é mais difícil, acirram-se movimentos protecionistas. Vejamos que o mercado de trabalho sempre foi um espaço reservado para os nacionais, a incorporação dos imigrantes, em regra, se dá nas piores ocupações e com menores salários, nos momentos de expansão da economia. Quando há baixo crescimento econômico, a disputa no mercado de trabalho é mais acirrada. Assim, o argumento de que os custos do estado de bem-estar reduzem a oferta de empregos afeta sua legitimidade junto a segmentos da

39 Deve-se considerar que há diferenças entre os programas de transferência de renda da Europa e os praticados nos países da América do Sul. 
classe trabalhadora. O carater universal de proteção social se torna mais complicado quando se inclui o acesso dos estrangeiros imigrantes à proteção pública, fator fomentado pela integração regional. Vejamos a análise de Clayton e Pontusson (2006, p. 158-9):

[...] la preferencia por el bienestar de seguro social puede reflejar ansiedades sobre una mayor integración europea, desde el momento en que la legislación de la Unión Europea proscribe la discriminación basada en la nacionalidade. Como las prestaciones del seguro social se basan tipicamente en la renta del empleo, dichos programas evitan el problema político de que los extranjeros se aprovechen de las generosas prestaciones.

Podemos inferir que situações de elevado desemprego, fragmentação das classes trabalhadoras e redução do poder dos sindicatos favorecem uma crise de identidade de classe que afeta a legitimidade do estado de bem-estar e reduz a luta pelo objetivo de promover a igualdade social. $\mathrm{O}$ individualismo, incentivado pelas ideologias liberais da competitividade e concorrência, é contrário ao sentimento de solidariedade e igualdade social, valores que estão na base do estado de bem-estar.

\section{Custo político das reformas do estado de bem-estar}

Na década de 1980, os partidos conservadores passaram a atacar o estado de bem-estar e exigir reformas liberais, conforme as políticas de Margaret Thatcher e Ronald Reagan. Analisando os efeitos desse intenso ataque ideológico, os trabalhos de Pierson (1994 e 1996) constataram a resistência do estado de bem-estar em razão da sua forte legitimação popular e dos riscos políticos que envolveriam reformas radicais. A sua análise indicou que o ataque ideológico ao estado de bem-estar teve reduzido efeito nos governos para adotar medidas de reformas radicais, tendo levado a uma reestruturação de alguns serviços e programas, sem, no entanto, afetar sua legitimidade. Assim, não houve um desmonte no estado de bem-estar europeu, mas sim, uma reestruturação do pacto pós-guerra e dos programas sociais.

No debate sobre as reformas no estado de bem-estar na Europa, Clayton e Pontusson (2006, p.122-123) criticam a posição de Pierson (1996) de que "las reformas y recortes del Estado de bienestar han sido de un alcance estrictamente limitado" e levantam pontos contraditórios da sua análise de que "el poder de los sindicatos y de los partidos de izquierda se há reducido considerablemente en muchas sociedades industriales avanzadas". Para os autores, o argumento de que as reformas foram limitadas num contexto de redução do poder dos sindicatos é paradoxal se considerar as explicações de que o estado de bem-estar resulta da pressão dos trabalhadores. 
Para Clayton e Pontusson (2006, p.122-125), Pierson (1996), ao afirmar que há limites nas reformas num contexto de redução do poder dos sindicatos, explica a resistência do estado de bem-estar ligada a três fatores: a) "el Estado de bienestar representa en estos momentos el status quo, con todas las ventajas políticas que dicho estatus confiere"; b) "los recortes en matéria de bienestar tienden a estar associados con elevados costes electorales por la simple razón de que los programas básicos de bienestar gozan de una amplia legitimidade entre la población"; c) "la movilización exitosa de grupos bien organizados que representan los interesses de los consumidores de las prestaciones del bienestar (como los jubilados) y de los empleados del Estado de bienestar".

Pierson (2006) afirma que há problemas nas análises sobre os regimes de bem-estar, há falta de um conceito comum sobre o que se considera o estado de bem-estar, sobre quais dados são relevantes e ainda, dificuldades de elaboração teórica.

Clayton e Pontusson (2006), contrapondo-se às análises de Pierson (1996), afirmam que existem mudanças no alcance e organização da provisão pública de bem-estar no Reino Unido, EUA e países da OCDE. Criticam a análise de Pierson (1996) centrada no corte de direitos e nas prestações do estado de bem-estar. Explicam que o recente corte de gastos e reforma do estado de bem-estar devem ser considerados no contexto de crescente desigualdade social e insegurança no mercado de trabalho. As mudanças no mercado de trabalho afetam o estado de bem-estar, independentemente dos cortes e reformas de programas sociais que os governos promovem. A crise do modelo universal de bem-estar da Escandinávia mostra a sua relação com o emprego. Não se pode medir o tamanho do estado de bem-estar só pelo gasto em relação ao PIB, devem ser consideradas as mudanças na provisão dos serviços públicos, na organização do setor público e não só em programas sociais analisados de forma isolada.

Para Clayton e Pontusson (2006), a mobilidade de capital (investimentos) e o envelhecimento da população afetam o estado de bem-estar. Ao contrário de Pierson (1994), afirmam que os interesses sociais jogam um papel mais importante que os esquemas político-eleitorais. O desemprego de massa tem se convertido numa característica dos mercados de trabalho na Europa, embora exista apoio popular ao núcleo dos programas de bem-estar, o desemprego torna mais difícil manter seu universalismo.

A fragmentação da classe trabalhadora favorece o discurso conservador que apresenta a necessidade da reforma do estado de bem-estar e a redução dos gastos públicos, levando ainda o setor público a ser visto como um problema. Nesse sentido, também se ataca a situação dos funcionários públicos, vistos como privilegiados num contexto em que a internacionalização da 
economia lança todos os trabalhadores em situação de maior risco e incerteza. Os segmentos das classes médias e altas passam a demandar isenção de impostos para cobrir seus gastos e não se comprometem na luta pela igualdade social e defesa do estado de bem-estar. As grandes empresas criam mecanismos de evasão fiscal, reduzindo os seus custos em impostos e também apoiando as mudanças na legislação do trabalho que reduz os encargos para contratar e demitir, sob o argumento da flexiseguridade.

Nesse sentido, os custos políticos com as reformas no estado de bem- estar são minorados, pois parte das classes médias e alta são favoráveis às mudanças e os segmentos mais afetados pelos cortes dos gastos públicos e deterioração dos serviços públicos estão nos segmentos dos trabalhadores com menores índices de sindicalização e com empregos mais precários. Dessa forma, os setores conservadores e o grande capital promovem um ataque ideológico aos gastos públicos, apresentados como geradores de perda de competitividade e entrave à ampliação dos empregos. $\mathrm{O}$ estado de bem-estar é reformado num sentido não igualitário, focalizado para os segmentos mais pobres ao mesmo tempo em que se fomenta a privatização de setores da saúde, educação e previdência social. O objetivo do pleno emprego foi deixado de lado e surge outro paradigma na União Europeia, empregabilidade e flexiseguridade. $\mathrm{O}$ conceito de flexiseguridade está relacionado às mudanças no mercado de trabalho, com redução dos direitos laborais e a política de mínimos sociais.

Ese modelo ha sido tomado desde la Unión Europea como paradigma para conjugar la flexibilidad del mercado laboral y el mantenimiento de un modelo social europeo que provea unos niveles mínimos de seguridad. O, en un sentido más amplio, para garantizar la flexibilidad de los mercados sin menoscabo de la cohesión social. ${ }^{40}$

\section{Estado de bem-estar, as mudanças demográficas e na família}

O pacto entre gerações e o suporte familiar também se modificou em razão das mudanças demográficas, menor taxa de natalidade e envelhecimento da população e um papel mais positivo das mulheres em termos de trabalho e autonomia econômica. Conforme a análise de Esping-Andersen (2011, p.14):

Los nacientes riesgos de la sociedade postindustrial provienen principalmente de la revolución que se está desarrollando tanto en los mercados de trabajo como en las familias. Necesitamos urgentemente

40 LEONARDi, L., MARTÍN ARTILES, A., MOLINA, O., CALENDA, D., CARRASQUER OTO, P. (2011). ¿Es exportable la flexiguridad? Um estúdio comparado de Italia y España. Cuadernos De Relaciones Laborales v. 29, n. 2, p. 417-443. 
una concepción mejor de qué es lo que hoy mueve el comportamento de la família y del empleo en el sector de servicios. Para la mayoría de los analistas, esta fuerza impulsora es de tipo macroscópico y global. Esta es certamente una parte de la historia, pero también se halla en juego una potente fuerza microscópica; a saber: las decisiones económicas de las famílias y, especialmente, de las mujeres.

As recentes análises de Esping-Andersen e Bruno Palier ${ }^{41}$ apontam três questões para pensar o estado de bem-estar europeu: a família e a revolução no papel da mulher; filhos e igualdade de oportunidades; envelhecimento e equidade.

O primeiro ponto é a necessidade de uma política de igualdade entre homens e mulheres que diminua a carga desigual de trabalho da mulher na família e nos cuidados dos filhos, permitindo seu ingresso e permanência no mercado de trabalho. Nesse ponto, o apoio do setor público no atendimento de crianças pequenas ( 0 a 3 anos) precisa ser desenvolvido e funcionar como incentivo ao trabalho das mulheres e, ao mesmo tempo, incentivar a maternidade. A pobreza é maior nas famílias em que a mulher não trabalha e isso afeta também as condições de vida das crianças. Assim, políticas voltadas para promover a igualdade de gênero também têm impactos positivos na redução da pobreza de crianças. Outro fator é a contribuição fiscal que é gerada pelo trabalho das mulheres, segundo os autores, mais do que compensaria os gastos públicos no atendimento das crianças.

A mudança no comportamento das mulheres em relação ao número de filhos afeta a evolução demográfica. "La rapidez del ritmo al que envejece la sociedade es en gran medida efecto de esta revolución feminina" (p.20).

O divórcio é apontado pelos autores como um fator que afeta as condições de vida dos filhos e que, nos casais de menor renda, pode elevar o risco de pobreza para as crianças. A revolução feminina afeta também os cuidados domiciliares de pessoas idosas e de crianças, faz crescer a demanda por serviços públicos nessa área. Os cuidados, em instituições privadas, para idosos e crianças, são caros e muitas famílias não podem arcar com essas despesas. A mudança de comportamento dos homens nos cuidados dos filhos e nas tarefas domésticas também tem sido registrada pelos pesquisadores. As mulheres com maior autonomia têm maiores condições de negociar com os homens sobre a divisão de tarefas.

As políticas sociais devem fortalecer a autonomia das mulheres, sua entrada e permanência no mercado de trabalho e, ao mesmo tempo, possibilitar que tenham filhos. Esse é um desafio para o estado de bem-estar europeu,

41 Los três grandes retos del Estado del bienestar. Barcelona: Editorial Ariel, 2011. 
rever as políticas familistas que colocam o peso de cuidados e proteção na família e penalizam as mulheres.

O segundo ponto enfatizado pelos autores é a necessidade de criar políticas que de fato melhorem a igualdade de oportunidade e de resultados para todas as crianças, especialmente para as que vivem em famílias de menores rendas, com dificuldades para dedicar tempo ao seu desenvolvimento cognitivo e com déficit cultural.

Las bases cognitivas decisivas quedan fijadas en el curso de la primera infância. Lo que há tenido lugar en la etapa pré-escolar es fundamental para la motivación y las capacidades de aprendizaje del niño una vez há entrado en la escuela. Los Orígenes sociales, pues, nos han marcado ya profundamente antes de que el Estado del bienestar intervenga de verdade en nuestras vidas. Conclusión lógica: deberíamos interesarnos por lo que sucede en el seno de la familia antes que en las politicas de enseñanza. (p.57).

Nesse sentido, defendem a expansão do atendimento público para crianças pequenas, uma vez que em muitos países o atendimento a partir dos 3 anos já existe, mas também deve ser ampliado. Os autores argumentam que há pesquisas que indicam serem melhores os rendimentos escolares e o perfil da qualificação profissional de pessoas que tiveram um bom atendimento na primeira infância. Nesse sentido, não basta uma escolarização igualitária, é preciso não gerar um déficit de atenção na primeira infância, pois crianças que não têm uma socialização com estímulos cognitivos têm defasagem quando entram na escola regular e isso gera desigualdade de resultados na trajetória educacional e profissional. Outro ponto analisado é o tempo dedicado pelos pais na atenção aos filhos e a qualidade dessa atenção com estímulos cognitivos. Os casais de melhor nível de renda e de qualificação dedicam mais tempo para seus filhos e os casais com menores renda e qualificação e especialmente os lares monoparentais têm dificuldades em dar atenção e estímulos cognitivos para os filhos. Os filhos de imigrantes têm maiores dificuldades no processo de qualificação e estudos, o que deve ser revertido a partir de políticas voltadas para esse segmento, em busca de maior igualdade de oportunidades.

Os autores afirmam que o atual quadro de crescentes desigualdades sociais reforça a herança social das crianças. "Según ciertas investigaciones norte-americanas, un hijo de padres pobres tiene un $42 \%$ de possibilidades de ser él tambien pobre en la edad adulta."(p.64). No entanto, os autores mostram que além da renda familiar, é preciso considerar o tempo dedicado para a tenção aos filhos e o fator cultural da família. Defendem políticas de cuidados para as crianças antes da idade escolar, como forma de diminuir a influência "do capital cultural" e da situação socioeconômica dos pais, como forma de criar igualdade de oportunidades e de resultados para as crianças. 
O terceiro ponto analisado é o envelhecimento populacional e a forma de atendimento dos idosos. As reformas de aposentadorias sempre colocam as vantagens em se aumentar o tempo de trabalho, reduzir o valor das aposentadorias e incentivar os planos privados de pensão e maiores responsabilidades da família nos cuidados de idosos. Os autores argumentam que é preciso redefinir um "contrato intergeracional" a fim de assegurar uma justiça distributiva nos custos e benefícios entre as gerações. Criticam a posição dos que pretendem impor maiores responsabilidades para as famílias nos cuidados de idosos, pois esse peso seria distribuído de forma desigual na família. As mulheres teriam maiores cargas de trabalho doméstico, o que reduziria seu ingresso no mercado de trabalho, com consequências negativas do ponto de vista fiscal e em sua autonomia. Os planos privados fomentam a desigualdade de condições para os aposentados e contam com aporte de incentivos fiscais, o que eleva a desigualdade social. O sistema público de aposentadoria deve ser reformado no sentido de não colocar peso excessivo sobre os trabalhadores ativos para não reduzir a oferta de emprego, assim, enfatizam a necessidade ajustes nas contribuições com progressividade para os setores com maiores rendas. Argumentam que nas sociedades pós-industriais, na sociedade do conhecimento e, devido a entrada das mulheres no mercado de trabalho, as trajetórias profissionais estão mais diversificadas, ao contrário do modelo estandardizado do período da sociedade industrial.

Para os autores Esping-Andersen e Palier (2011), os fatores que mais afetam o estado de bem-estar são: as mudanças demográficas, a entrada das mulheres no mercado de trabalho e o envelhecimento da população. Não há, nas argumentações dos autores, referências explícitas à internacionalização da economia como um fator que reduz os direitos sociais dos trabalhadores. Também não há referência explícita nessa obra, da pressão que o Tratado de Maastricht representa para os países do sul da Europa na contenção de gastos públicos.

Conforme Sônia Draibe (2007), as teorias sobre o estado de bem-estar enfatizam os diferentes graus de mercantilização/desmercantilização dos bens e serviços, a familiarização ou desfamiliarização como parâmetros para avaliar a atuação do estado e do mercado na proteção social. As recentes publicações de Esping-Andersen ${ }^{42}$ enfatizam a importância do papel da mulher na sociedade e seu impacto na proteção social. No entanto, outras dimensões carecem de maior destaque no debate sobre os regimes de proteção

42 ESPING-ANDERSEN, G. (ed.) Why we need a new welfare state? Oxford University Press, 2002.

ESPING-ANDERSEN, G. The incomplete revolution. Oxford: Polity Press, 2009. 
social. O caráter político das reformas e sua relação com os interesses de classe evidenciam no atual contexto uma ofensiva do capital contra os direitos do trabalhador.

Mioto (2008) afirma que ao se retirar a centralidade do Estado na provisão de bem-estar, o pluralismo de bem-estar ${ }^{43}$ revela o eufemismo das políticas sociais de corte neoliberal que leva a maior responsabilização das famílias na provisão da proteção social. Os valores da solidariedade, fraternidade e caridade desenvolvidos nas esferas familiares e nas redes filantrópicas são divulgados como alternativas à proteção social pública. O "terceiro setor" também ganha destaque e reforça o modelo de proteção centrado no papel da família nos cuidados de seus membros.

Nesse contexto, a condução das políticas sociais na Europa, especialmente nos países da Europa do Sul, vêm demonstrando "o processo de familiarização" da proteção social através da ampliação dos gastos das famílias para a inserção social dos jovens, dificuldades em conciliar o cuidado das crianças e idosos com o trabalho remunerado das mulheres e os custos crescentes da carga de cuidados de longa duração frente ao aumento do tempo de dependência dos filhos (NAVARRO, 2000; SARACENO, 1997; CABRERO, 2001; MIOTO, 2008, p.140)

A pesquisa bibliográfica ${ }^{44}$ sobre as mudanças no estado de bem-estar indica que as questões de gênero e as relações familiares são importantes para a análise dos regimes de proteção social, revelam valores culturais e relações de poder dentro do espaço doméstico e a forma como as políticas sociais podem ou não favorecer a igualdade e autonomia das mulheres em cada sociedade. As questões de classe social e os condicionantes do mercado de trabalho, centrais na análise da sociedade capitalista, não são suficientes para explicar os regimes de bem-estar social de forma isolada das questões de gênero e familiares.

A dinâmica social moderna e as transformações nas relações familiares levam à maior individualização, alterando os laços de solidariedade familiar. Os arranjos familiares são mais diversificados e incluem também questões sobre a diversidade sexual. Essa complexa dinâmica favorece a individualização, ou como Giddens ${ }^{45}$ afirma, eleva o grau de reflexividade, o que fomenta a demanda por proteção das esferas do mercado e do Estado uma vez que transforma os espaços tradicionais da proteção familiar. Esse processo ocorre ao mesmo tempo em que há alterações nas relações laborais e o reforço de políticas sociais de caráter familistas, colocando o sistema de proteção social

\footnotetext{
43 Que também ficou conhecido como welfare mix.

44 Autores citados ao longo do texto.

45 GIDDENS, Anthony. A transformação da intimidade. Sexualidade, amor e erotismo nas sociedades modernas. São Paulo: UNESP, 1993.
} 
em crise, tanto nas esferas tradicionais da família e do mercado de trabalho como também na esfera pública.

Aspectos demográficos também são importantes. As mudanças na longevidade e na taxa de natalidade criaram demandas por novos serviços de cuidados. O envelhecimento populacional numa economia que reduz a incorporação do trabalho na esfera da produção exige mudanças na forma e padrão de financiamento do sistema de aposentadorias e pensões. A fragilidade dos laços de solidariedade intergeracional e intrafamiliar faz dos riscos da vida moderna um campo de interesse para o mercado. Vende-se seguridade! Individualiza-se a busca pela proteção social, que assume a forma de um produto disponível no mercado, com diferente nível de abrangência. Nesse contexto, a proteção pública torna-se focalizada para segmentos que não podem buscar no mercado sua segurança social. Assim, o discurso conservador transforma os direitos sociais em bens de mercado, planos privados de previdência social, de saúde etc. A mercantilização dos serviços sociais afeta a proteção social pública.

\section{Proteção social no Mercosul}

Diferentemente da internacionalização do capital, os direitos sociais são nacionais e direcionados para os cidadãos ou estrangeiros residentes em determinado país. Ainda não há um direito social comunitário que assegure, por exemplo, direito previdenciário que se possa exigir em todos os países, com a mesma cobertura e garantias. Embora existam organismos internacionais de seguridade social ${ }^{46}$, o que se internacionaliza é a economia e não a proteção social. No entanto, com o processo de globalização ${ }^{47}$, intensificado no final do século XX, colocam-se em questionamento as limitações sobre o acesso aos direitos sociais, buscando como fundamento para essa crítica a supremacia dos direitos humanos em relação aos direitos de cidadania ${ }^{48}$. Esse debate fica mais evidente quando se analisa o problema das imigrações e das populações em regiões de fronteiras, pois essas pessoas demandam proteção social apesar de não terem o status de cidadão e nem o reconhecimento legal de seu caráter de estrangeiro residente. O processo de integração

\footnotetext{
46 Associação Internacional de Seguridade Social (AISS); Conferência Interamericana de Seguridade Social (CISS); e Organização Ibero-americana de Seguridade Social (OISS).

47 "A globalização pode ser pensada como um complexo processo desencadeado pela forma de produção e circulação de mercadorias, exponenciado a partir da segunda metade do século XX, em virtude de um enorme avanço tecnológico. Ao lado do avanço da internacionalização da produção, a globalização também adquire o caráter de um movimento político, cultural e valorativo, na medida em que difunde uma maneira de ser, de pensar e um tipo de sociedade como forma hegemônica, a sociedade capitalista." (COSTA, 2006, p.82).
}

48 Conforme análise de FERRAJOLI, Luigi. (2005) 
regional também favorece o questionamento dos critérios de acesso aos direitos sociais ao permitir a mobilidade das pessoas, especialmente na situação de trabalho e de residência nos diferentes países do bloco.

Quando são discutidos os "direitos sociais", a polêmica recai sobre o financiamento dos gastos públicos na oferta de serviços e benefícios para a população. Diferentemente das prestações negativas, em que o Estado se abstém de agir para dar espaço à liberdade do cidadão e do mercado, os direitos sociais exigem uma prestação positiva e geram custos para a sua provisão pelo Estado, têm impactos tributários além de desmercantilizar o acesso a bens e serviços. Assim, os direitos sociais incidem diretamente na questão da distribuição da riqueza socialmente produzida e nas esferas de atuação do mercado, especialmente nas áreas de serviços sociais.

Considerando que os direitos sociais exigem do Estado uma obrigação ou prestação positiva, gerando então custos na sua efetivação, coloca-se a questão de como montar um sistema de financiamento da proteção social de abrangência regional. Em que medida é possível criar uma fonte de financiamento para proteção social que transcenda os limites do Estado nacional? A integração regional é o resultado de uma vontade política, realizada sob determinadas condições objetivas, tais como o nível de crescimento econômico, capacidade técnica e de gestão, o nível de infraestrutura social. Assim, se houver um forte apoio da sociedade à decisão política de aprofundar o processo de integração, é possível uma harmonização da legislação trabalhista, previdenciária e maior convergência das políticas sociais. O desafio é integrar países com diferentes níveis de desenvolvimento econômico gerando uma convergência positiva. $\mathrm{Na}$ análise sobre a integração europeia, há posições que defendem que houve melhora no padrão de vida da população dos países mais pobres do bloco, conforme segue:

De qualquer modo, e ao contrário do pressuposto doutrinário segundo o qual a integração num mercado ampliado inevitavelmente aumentaria a distância entre unidades ricas e pobres (ver as histórias nacionais da Itália ou da Espanha), até aqui a União Europeia provou o oposto: a integração regional pode não só lidar com diferenças econômicas nacionais no ponto de partida, mas também diminuí-las ao longo do tempo. (SCHMITTER, 2010, p.19).

No entanto, a possibilidade do processo de integração resultar benéfica para os países mais pobres, depois da crise de 2008, parece mais distante hoje. Existem posições divergentes sobre os impactos positivos da formação da União Europeia nas condições de vida das classes trabalhadoras. Navarro (2010) indica que para alguns países, a criação do Euro teve impacto negativo no financiamento das políticas sociais e no nível de crescimento econômico, favorecendo a redução dos salários e a queda no nível de demanda dentro 


\section{Lucia Cortes da Costa}

da economia. Há indefinições sobre a questão tributária e os mecanismos para controle das dívidas públicas em países como Grécia, Espanha e Portugal. Esse contexto de crise econômica gera efeitos negativos no sistema de proteção social.

No Mercosul, o debate sobre a necessidade de inserir a proteção social na agenda política do bloco resultou no Acordo Multilateral de Seguridade Social (1997) e na Declaração Sociolaboral (1998). Cresceu o debate sobre a necessidade de articular políticas sociais na região, levando a criar a Reunião de Ministros e Autoridades do Desenvolvimento Social - RMADS, em 2000.

Carta de Buenos Aires, adotada por ocasião da XVIII Reunião do Conselho do Mercado Comum, em 30 de junho de 2000, determina que o Foro de Consulta e Concertação Política do MERCOSUL promova a institucionalização de uma Reunião de Ministros e Autoridades Responsáveis em Matéria de Desenvolvimento Social. ${ }^{49}$

O Programa de Trabalho do Mercosul - 2004 a 2006 $6^{50}$, inseriu a dimensão social, com a proposta de ampliar a participação da sociedade civil e dar maior visibilidade ao Mercosul através de projetos culturais. Nos temas sociais, destacou as tarefas para a Reunião de Ministros e Autoridades de Desenvolvimento Social - RMADS.

Delinear e desenvolver, durante 2004, estruturas de articulação dos centros de investigação social dos quatro Estados Partes para a condução de reflexões sobre os temas sociais, entre outros aqueles referidos à pobreza, intercâmbio de experiências nacionais exitosas em programas e projetos sociais e desenvolvimento de indicadores sociais harmonizados que possam servir de base para o estabelecimento de metas para a política social dos países do MERCOSUL.

Os esforços para criar um processo de convergência das políticas sociais resultou na criação do FOCEM ${ }^{51}$ - Fundo de Convergência Estrutural do Mercosul (2004) e no Instituto Social do Mercosul ${ }^{52}$ (2007). As Cúpulas Sociais expressam a preocupação em colocar o Mercosul como um projeto de integração para além da esfera comercial. Destaque para a Cúpula Social de Córdoba (2006) e o comunicado conjunto dos Presidentes dos Estados Parte, em 20 e 21 de junho de 2006, no qual reconhecem a importância e necessidade de criar um Plano Estratégico de Ação Social.

\footnotetext{
49 MERCOSUL/CMC/DEC. $\mathrm{n}^{\circ}$ 61/00.

50 MERCOSUL/CMC/DEC. nº 26/03. Programa de trabalho do MERCOSUL. 2004 - 2006.

51 O CMC, pelas Decisões no 45/04 e 18/05, criou o Fundo para a Convergência Estrutural do MERCOSUL (FOCEM).

52 MERCOSUL/CMC/DEC. $n^{\circ}$ 03/07. XXXII CMC - Rio de Janeiro, 18/I/07.
} 
A Reunião de Ministros de Desenvolvimento Social - RMADS busca articular uma visão de política social para a região, com o objetivo de criar estratégias para reduzir os índices de pobreza, de analfabetismo, exploração sexual de crianças e o trabalho infantil, criar políticas para promover a igualdade de gênero e demais fatores necessários ao desenvolvimento social. Outro fator importante é a construção de indicadores sociais que permitam a avaliação e monitoramento das políticas sociais, a partir de banco de dados oficiais dos governos na região, com metodologia comum.

Constata-se nas Atas das Reuniões de Ministros e Autoridades de Desenvolvimento Social - RMADS, declarações de intenções sobre a necessidade de políticas sociais integradas, no entanto, há fraca institucionalidade para concretizar tais medidas no Mercosul.

MERCOSUR parecería experimentar la paradójica situación de no lograr definir una agenda social por mínima que fuera, pero sí actuar según un discurso maximalista que propone la integración de políticas sociales en niveles aparentemente mucho más elevados de los que alcanzó la Unión Europea en este campo de reconocida y difícil integración. (DRAIBE; RIESCO, 2009, p.107).

Para criar uma maior simetria entre os países do bloco, é preciso um esforço político e um aporte de recursos que permita alargar os investimentos em infraestrutura urbana e serviços públicos de qualidade. Diferente da União Europeia, o Mercosul não tem um país com uma economia com o nível da Alemanha e sociedades com infraestrutura já instalada. Todos os países do bloco enfrentam dificuldades para alargar o bem-estar da população e manter estabilidade macroeconômica com controle da inflação, as taxas de juros oneram o consumo e a produção, além de ainda haver problemas de competitividade em vários setores, há precariedade de infraestrutura de transportes. O Focem ${ }^{53}$ é uma iniciativa tímida, já que o aporte de recursos é insuficiente ${ }^{54}$ diante das demandas de investimentos.

\footnotetext{
53 O FOCEM está destinado a financiar programas para promover a convergência estrutural; desenvolver a competitividade; promover a coesão social, em particular das economias menores e regiões menos desenvolvidas, e apoiar o funcionamento da estrutura institucional e o fortalecimento do processo de integração.

54 CONTRIBUIÇÕES DOS ESTADOS PARTES: ARGENTINA 33.750.000; BRASIL 87.500.000; PARAGUAI 1.250.000; URUGUAI 2.500.000. TOTAL DE RECEITAS 125.000.000. Em dólares dos EEUU.

RETRIBUIÇÃO A PROJETOS. DISTRIBUIÇÃO DOS RECURSOS POR PAÍSES: ARGENTINA 9.850.664; BRASIL 9.850.664; PARAGUAI 57.350.664; URUGUAI 37.350.664 PROGRAMA IV 100.Fonte: MERCOSUL/CMC/DEC. N ${ }^{\circ}$ 28/06000. TOTAL 114.502.656.
} 
Os países do Mercosul têm grande assimetria econômica e social, com distintos sistemas de proteção social. Há uma diversidade cultural na região, diferentes processos demográficos ${ }^{55}$ e de mobilidade interna do trabalho, áreas urbanas e rurais com diferentes níveis de infraestrutura. No entanto, há em comum a necessidade de construir sistema de proteção social que inclua os segmentos mais pobres da população, é preciso elevar o nível de qualificação dos trabalhadores, melhorar índices de escolaridade e de saúde. O desemprego e a economia informal ainda afetam muitos trabalhadores da região. Nesse sentido, não há de fato uma sociedade salarial nos países do Mercosul, nos mesmos padrões descritos por Castel (1998) na análise sobre a Europa. A proteção social pública ainda é subsidiária da privada e as famílias arcam com os cuidados de idosos e crianças pequenas, a oferta de educação básica ainda não é universal na região e os problemas com a má qualidade dos serviços públicos contribuem para que os segmentos de classe média e alta busquem serviços privados de saúde e educação. Isso favorece uma visão individualista da proteção social e uma pressão para que o Estado conceda incentivos fiscais para os gastos privados em educação, saúde e previdência.

Com o avanço no processo de integração regional, o Conselho Mercado Comum, pela Decisão no 67/10, em 16/12/2010, enviou para a RMADS o documento "Eixos, Diretrizes e Objetivos Prioritários do Plano Estratégico de Ação Social do Mercosul (PEAS)", elaborado pela CCMASM - Comissão de Coordenação de Ministros de Assuntos Sociais do Mercosul. Dentro desse documento, colocam-se as prioridades do combate à pobreza, garantia do direito à alimentação, expansão da oferta de educação e da integração nos sistemas de ensino na região, políticas contra a exploração do trabalho infantil e da exploração sexual de crianças e adolescentes, propostas de atendimento socioeducativo para adolescentes infratores nas regiões de fronteiras, medidas para garantir acesso aos serviços de saúde, com especial atenção nas regiões de fronteiras, questões sobre a agenda do trabalho decente e meio ambiente. Considerando os dez eixos do Plano Estratégico de Ação Social do Mercosul, pode-se ter uma ideia da sua abrangência e do tamanho dos desafios apresentados. $\mathrm{Na}$ análise do documento, fica evidente a preocupação no atendimento dos segmentos mais pobres e com piores inserções no mercado de trabalho.

\footnotetext{
55 O Paraguai tem uma população com muitas crianças e jovens, já os demais países apresentam índices de envelhecimento da população, sem, no entanto, resolver os problemas relacionados aos cuidados de crianças e adolescentes. A taxa de dependência (crianças e idosos) representa um desafio para o financiamento do sistema de proteção social, especialmente o regime contributivo de aposentadorias e pensões. Há demandas de serviços públicos para os cuidados de crianças e de idosos que favoreçam maior autonomia para a família e o trabalho remunerado das mulheres.
} 


\section{PLANO ESTRATÉGICO DE AÇÃO SOCIAL DO MERCOSUL - PEAS $^{56}$}

Eixo I - Erradicar a fome, a pobreza e combater as desigualdades sociais. Eixo II - Garantir os Direitos Humanos, a Assistência Humanitária e a igualdade étnica, racial e de gênero.

Eixo III - Universalizar a Saúde Pública.

Eixo IV - Universalizar a Educação e Erradicar o Analfabetismo.

Eixo V - Valorizar e Promover a diversidade cultural.

Eixo VI - Garantir a Inclusão Produtiva.

Eixo VII - Assegurar o acesso ao Trabalho decente e aos Direitos Previdenciários.

Eixo VIII - Promover a Sustentabilidade Ambiental.

Eixo IX - Assegurar o diálogo Social.

Eixo X - Estabelecer mecanismos de cooperação regional para a implementação e financiamento de políticas sociais.

O sistema de proteção social construído nos países da região a partir da década de 1930 foi marcado pela exclusão dos segmentos mais pobres, tinha como objetivo favorecer a industrialização e formar um operariado urbano e um corpo de funcionários públicos. Assim, a proteção social era limitada a esses segmentos das classes trabalhadoras, bem como o acesso ao crédito imobiliário ${ }^{57}$. O Uruguai e Argentina tiveram uma trajetória mais universalista na proteção social, com um papel mais ativo da proteção pública na área da saúde e educação, mas as pensões e aposentadorias foram vinculadas a contribuições. O Brasil tinha, antes da Constituição Federal de 1988, um modelo contributivo focado para as relações de emprego, deixando de fora os trabalhadores da economia informal e até a década de 1970, os trabalhadores domésticos e rurais. O Paraguai apresenta os piores índices de cobertura previdenciária e de serviços sociais, com a maioria da sua população excluída da proteção social pública.

A partir da década de 1990, em razão da elevação do nível de desemprego e dos ajustes neoliberais ${ }^{58}$, os países da região adotam uma estratégia

\footnotetext{
56 MERCOSUL/CMC/ DEC. $n^{\circ}$ 67/10.

57 No Brasil, o fenômeno das favelas expressa a falta de políticas públicas para moradia das camadas mais pobres. O Governo Fernando Henrique Cardoso, após o desmonte do BNH, passou a adotar uma política habitacional voltada para oferta de crédito a setores populares, mas que devido às exigências dos agentes financeiros, excluía os segmentos mais pobres e sem comprovação de rendas. Somente com o Programa de Aceleração do Crescimento - PAC, o Programa Minha Casa Minha Vida, governo Dilma, passou a beneficiar famílias mais pobres, além de estimular todo o mercado imobiliário.
}

58 Abertura econômica, geração de superávit primário, pagamento de juros da dívida pública e contenção de gastos públicos, controle da inflação. 
de atendimento aos segmentos mais pobres via programas de transferência de rendas. Essa estratégia consistiu numa medida de urgência diante dos graves índices de pobreza na região e da incapacidade de incluir no mercado de trabalho um contingente de pessoas, especialmente as de menor qualificação profissional. $\mathrm{O}$ combate à pobreza foi reduzido a medidas de inclusão no mercado de consumo os segmentos mais pobres ${ }^{59}$, sem alterar demais fatores estruturais, tais como a regressividade dos impostos, falta de reformas que fossem capazes de impor uma redistribuição vertical da renda e uma melhora na qualidade e nível de cobertura dos serviços públicos. Os programas de transferência condicionada de rendas surgem no mesmo contexto em que reformas neoliberais impediam a construção de um sistema de proteção social universal e inclusivo. Assim, nesse momento, as medidas focalizadas para os segmentos mais pobres não estavam articuladas a uma ampliação do Estado em políticas sociais universais. Em razão do apelo ideológico difundido na crítica ao Estado e sua alegada ineficiência, a sociedade passou a ver os serviços públicos como serviços para os pobres e o setor privado como serviços de melhor qualidade ${ }^{60}$. Assim, o cumprimento das condicionalidades dos programas de transferência de rendas, matrícula e frequência escolar e acompanhamento de vacinações e medidas preventivas de saúde, embora importantes para dar acesso à população mais pobre a essas políticas sociais, não foram acompanhados de uma melhora na oferta e qualidade desses serviços. Tal contexto de ajustes neoliberais reduziu o impacto dos programas de transferência de rendas nos resultados da educação e saúde. No entanto, marcou o início de uma orientação das políticas sociais para atender aos segmentos mais pobres, construindo uma nova percepção sobre o papel do Estado na provisão de meios de subsistência das famílias. ${ }^{61}$ De uma forma contraditória, ao mesmo tempo em que houve um ajuste neoliberal, por força desse mesmo ajuste, se desenvolveu a consciência de que o Estado tem responsabilidades com a população que mais sofre as suas consequências. Em período de baixo crescimento econômico e elevado desemprego, não há como esperar que só

\footnotetext{
59 Não se pode esquecer que os valores transferidos estão muito longe de assegurar condições mínimas de consumo para a população.

${ }^{60}$ Não é apenas uma questão ideológica, os serviços públicos carecem de investimentos e melhoria na capacidade e qualidade do atendimento.

61 "Quando do lançamento do Programa Brasil Sem Miséria, o Bolsa Família atendia a 13 milhões de famílias, que correspondiam a cerca de 50 milhões de pessoas. A cobertura do programa deve passar de cerca de 13,3 milhões de famílias, alcançada ao final de 2011, para 13,6 milhões de famílias ao fim de 2012, finalmente alcançando 13,8 milhões de famílias em dezembro de 2013"..(MDS, Relatório de Gestão, 2011 -Senarc, 2012) Disponível em: <http://www.mds.gov.br/bolsafamilia>. Acesso em: 20 nov. 2012.
} 
a família e o mercado produzam bem-estar. $\mathrm{O}$ acesso à renda passou a ser incorporado ao discurso dos direitos sociais como garantia da sobrevivência numa sociedade de mercado que não consegue incluir todos.

Nos anos 2000, houve uma retomada da ideia de desenvolvimento na região, partidos de centro-esquerda chegam ao poder e os índices de pobreza passaram a ser encarados como desafios a serem superados a partir de uma ampliação da atuação do Estado, com uma valoração do processo de integração regional.

Las victorias electorales de Luiz Inacio Lula da Silva en Brasil (2002), Néstor Kirchner en Argentina (2003) y Tabaré Vázquez en Uruguay (2004), dieron paso a una renovación política y a la coincidencia temporal de líderes con una mayor cercanía de propuestas (más allá de las particularidades de cada país y los distintos niveles de vinculación entre sus partidos políticos), especialmente expresadas con respecto a la trascendencia de la integración regional como motor de un nuevo modelo de desarrollo para la región y como medio para su inserción internacional. ${ }^{62}$

Manteve-se a estratégia de programas de transferência de renda ${ }^{63}$, com uma ampliação da cobertura e com maior articulação das demais políticas socais. Os países do bloco adotaram como uma das prioridades do Mercosul Social o combate à pobreza, o Paraguai, com a vitória de Fernando Lugo, também adotou os programas de transferência de renda.

En este sentido, el Programa "Bolsa Familia" en Brasil, el "PANES" y luego el Plan de Equidad en Uruguay, "Plan Jefes y Jefas de Hogar" y luego Familias para la Inclusión Social en Argentina y "La red de promoción y protección social” y Tekoporá en Paraguay, presentan una característica común: el nexo entre las transferencias de ingresos y su contrapartida en el cumplimiento de ciertos requisitos para su percepción. ${ }^{64}$

Um fator importante para avaliar a atuação do Estado na área social é o volume de gastos públicos. Os países do Mercosul enfrentam o desafio de

\footnotetext{
62 GENEYRO, Ruben; VÁZQUEZ, Mariana. La ampliación de la agenda política y social para el Mercosur actual/7-18. Aldea Mundo. Revista sobre Fronteras e Integración Año 11, No. 20/ Mayo 2006 .

63 Uno de los aspectos más salientes de la implementación del PANES en Uruguay, puesto en comparación con otros Programas de Transferencias condicionadas de la región, está en que el gobierno uruguayo puso una fecha de inicio y una de finalización al PANES: abril de 2005 a diciembre de 2007. Todos los PTC del Mercosur y del resto de la región se han mantenido a lo largo del tiempo sin plazos de finalización. (MIRZA, 2010, p.73)

${ }^{64}$ ¿Es posible un nuevo Estado de bienestar en América Latina? La reconfiguración de las matrices de bienestar en el Mercosur. Coordinador: Christian Adel Mirza. Investigadores: Marcos Lorenzelli, Julio Bango. Ayudas a la investigación. Convocatoria 2007. Proyecto: CeALCI 16/07 Fundación Carolina. Madrid, 2010.
} 


\section{Lucia Cortes da Costa}

elevar os investimentos sociais. O Brasil, com maior PIB da região, é também o país mais desigual, o Paraguai acumula os piores índices, com menor PIB e elevada pobreza, a Argentina, depois das crises de 2002, ainda tem dificuldades de rearticular o crescimento econômico e ampliação de empregos, e o Uruguai, apesar das dificuldades econômicas, apresenta melhores indicadores sociais.

Segundo dados PNUD, 2008 (apud MIRZA, 2010, p.58), a mortalidade infantil, em 1000 nascidos vivos, é de 12 no Uruguai, 13,4 na Argentina, 23,6 no Brasil e 34 no Paraguai. Quanto ao número de leitos por 1000 habitantes, os dados são de 4,1 na Argentina, 2,9 no Uruguai, 2,6 no Brasil e apenas 1,3 no Paraguai.

En efecto según el Panorama Social de América Latina 2009 de CEPAL, junto a Bolivia, Nicaragua, Honduras, Guatemala y Ecuador; Paraguay ostenta un gasto público social inferior a U\$200 per cápita.

Si se lo compara con el resto de los países de la región objeto del presente trabajo - Argentina, Brasil y Uruguay - las diferencias son notorias, ya que precisamente estos tres países junto a Cuba tienen un gasto público social que sobrepasa los U\$1000 per cápita. (MIRZA, 2010, p.50).

Apesar de contar com menor rede de serviços públicos, podem-se aferir alguns esforços recentes do governo no Paraguai no sentido de ampliar a proteção social.

Durante el 2009 además se ha comenzado a implementar la instalación de las Unidades de Salud a la Familia (USF) que estarán constituidas por equipos integrados por médico, enfermera/o y auxiliares que contarán con el respaldo de agentes comunitarios y que en función de la disponibilidad locativa trabajará en puestos de salud o locales comunitarios. Se espera llegar al 2013 con casi 1900 USF. (MIRZA, 2010, p. 59).

Ao analisar a proteção social no Mercosul, pesquisas recentes ${ }^{65}$ apontam uma valorização da articulação entre política econômica e social, uma retomada do papel do Estado na provisão de bens e serviços. No entanto, permanecem históricos desafios de alterar um modelo de desenvolvimento que não inclui parcela da população, construir um grau de institucionalidade para as políticas sociais, definir indicadores de qualidade dos serviços públicos e alargar a sua abrangência. Essas questões exigem para além de medidas de políticas sociais, reformas estruturais na área fiscal e capacidade de pactos políticos que priorizem a redução das desigualdades sociais. O resultado dos ajustes neoliberais, com o agravamento das questões sociais, parece ter indicado uma alternativa para os países da região, uma escolha de um

65 DRAIBE y RIESCO (2009); MIRZA (2010). 
futuro mais democrático e igualitário. Nesse sentido, a análise de Menz (2005) é condizente ao afirmar que não há apenas uma força externa condicionando o estado de bem-estar, mas também existem diferentes reações, conforme a capacidade de organização política da sociedade. Afinal, o processo de globalização segue em curso, mas nos países do Mercosul, após uma virada política mais à esquerda, as respostas a essa pressão externa parecem ser diferentes das que foram dadas na década de 1990. Cabe ainda lembrar que criar um estado de bem-estar na região é parte de um processo de desenvolvimento que deve ser capaz de gerar maior articulação econômica, superando as históricas disputas comerciais e o protecionismo que sempre reaparece quando a balança comercial oscila entres os países ${ }^{66}$. A integração regional é uma estratégia de longo prazo, cabe acompanhar o desenrolar dos acontecimentos!

\section{Referências}

ADELANTADO, José, NOGUERA, José Antonio y RAMBLA, Xavier. CAMBIOS EN EL ESTADO DEL BIENESTAR. Políticas sociales y desigualdades en Espana. Disponível em: <http://www.mag-politicasociales.cl/documentos/adelantado.pdf> Acesso em: 20 de agosto de 2011

AGAMBEN, Giorgio. Estado de exceção. São Paulo: Boitempo, 2004.

ANTÓN, Antonio. Reestructuración del estado de bienestar. Madrid: Talasa, 2009.

BOSCHI, Renato; GAITÁN, Flavio. Intervencionismo estatal e políticas de desenvolvimento na América Latina. Caderno CRH, Salvador, v.21, n.53, p.305-322, maio/ago. 2008.

CASTEL, Robert. A insegurança social. O que é ser protegido? Petrópolis, RJ: Vozes, 2005.

A nova questão social: as metamorfoses da questão social: uma crônica do salário. Rio de Janeiro, Vozes, 1998.

COSTA Lucia Cortes da. (Org.). Estado e democracia: pluralidade de questões. Ponta Grossa: Editora UEPG, 2008.

A agenda social do MERCOSUL: a relação Estado nacional e integração regional. Em Pauta: teoria social e realidade contemporânea, v.6, n.24, 2009.

\footnotetext{
${ }_{66}$ Brasil e Argentina sempre estão comparando a balança comercial, que nos últimos anos tem ficado com superávit para o Brasil, o que levou o governo argentino a adotar medidas de controle de importações de produtos brasileiros. O Uruguai fica na disputa com Argentina nos conflitos com as papeleiras, Brasil e Paraguai, nos conflitos sobre o preço da energia elétrica e na questão campesina, com produtores brasileiros que plantam soja no país. A lista de conflitos ainda é grande.
} 
Integração regional e proteção social no contexto do MERCOSUL. In: MERCOSUL em múltiplas perspectivas: fronteiras, direitos e proteção social. Jussara Maria Rosa Mendes (et al.) (Orgs.). Porto Alegre: EDIPUCRS, 2007.

Os impasses do estado capitalista: uma análise sobre a reforma do Estado no Brasil. São Paulo: Cortez, Ponta Grossa: UEPG, 2006.

Keynes, uma análise social da teoria da demanda efetiva. Revista Pesquisa \& Debate, v.9, n. 13, 1998.

D’ARCY, François. Considerações sobre a União Européia para servir nas reflexões sobre o MERCOSUL. In: LIMA, Marcos Costa (Org.). O lugar da América do Sul na nova ordem mundial. São Paulo: Cortez, 2001.

DRAIBE, Sônia Miriam. Coesão social e integração regional: a agenda social do MERCOSUL e os grandes desafios das políticas sociais integradas. Caderno de Saúde Pública. Rio de Janeiro. 23 sup.2: S 174- S 183, 2007.

. Estado de bem-estar, desenvolvimento econômico e cidadania. In: HOCHMAN, Gilberto; ARRETCHE, Marta; MARQUES, Eduardo (Orgs.). Políticas públicas no Brasil. Rio de Janeiro: FIOCRUZ, 2007.

.; RIESCO, Manuel. El estado de bienestar social en américa latina: una nueva estrategia de desarrollo. Madrid: Fundación Carolina - CeALCI., 2009.

ESPING-ANDERSEN, G. (Ed.) Why we need a new welfare state? Oxford: Oxford University Press, 2002.

As três economias políticas do welfare state. Lua Nova, n.24, São Paulo, set. 1991,

Fundamentos sociales de las economias postindustriales. Barcelona: Ariel, 2011.

; PALIER, Bruno. Los três grandes retos del estado del bienestar. Barcelona: Ariel, 2011.

FAGNANI, Eduardo. A política social do Governo Lula (2003 - 2010) Texto para Discussão. IE/UNICAMP, n.192, junho 2011. Disponível em: < http://www.eco. unicamp.br/index.php/textos>. Acesso em: 02 outubro 2012.

FERRAJOLI, Luigi. A soberania no mundo moderno: nascimento e crise do Estado nacional. São Paulo: Martins Fontes, 2002.

. Direito e razão. São Paulo: Editora Revista dos Tribunais, 2005.

. Los fundamentos de los derechos fundamentales. 4.ed. Madrid: Trotta, 2009.

Derechos y garantias: la ley del más débil. 6 ed. Madrid: Trotta, 2006.

FIORI, José Luís. Estado de bem-estar social: padrões e crises. Disponível em: <http://www.iea.usp.br/iea/textos/fioribemestarsocial.pdf $>$. Acesso em: 2 outubro 2012. 
Integração regional e mudanças no estado de bem-estar ...

FLEURY, Sônia. Estado sem cidadãos: seguridade social na América Latina. Rio de Janeiro: FIOCRUZ, 1994.

GENEYRO, Ruben; VÁZQUEZ, Mariana. La ampliación de la agenda política y social para el Mercosur actual. Aldea Mundo. Revista sobre Fronteras e Integración, Año 11, No. 20, p. 7-18, Mayo 2006.

GIDDENS, A. El estado del bienestar en la sociedade europea moderna. En: JORNADA DE ECONOMIA CAIXA MANRESA, 9. 25 de mayo de 2004. Disponível: <http://www.uoc.edu/symposia/caixamanresa/jornadaeconomia/esp/ giddens.pdf $>$.

A transformação da intimidade: sexualidade, amor e erotismo nas sociedades modernas. São Paulo: UNESP, 1993.

GORZ, André. O imaterial. São Paulo: Editora Annablume, 2005.

HARDT, Michael; NEGRI, Antonio. Império. Rio de Janeiro: Editora Record, 2005.

HOBSBAWM, Eric J. Globalização, democracia e terrorismo. São Paulo: Companhia das Letras, 2007.

HOOGHE, L.; MARKS, G. Gobernanza estatocéntrica y gobernanza multinivel. En: MORATA, F. Gobernanza multinivel em la Unión Europea. Valencia: Tirant lo Blanch, 2004.

LEONARDI, Laura; MARTÍN ARTILES, Antonio; MOLINA, Óscar.; CALENDA, Davide; CARRASQUER OTO, Pilar. ¿Es exportable la flexiguridad? Un estudio comparado de Italia y España. Cuadernos De Relaciones Laborales, v.29, n.2, p.417-443, 2011.

MARSHALL, Thomas Humphrey. Política social. Rio de Janeiro: Zahar, 1965.

Cidadania, classe social e status. Rio de Janeiro: Zahar, 1967.

MENZ, Georg. Europeanisation meets organized capitalism. Oxford: Oxford University, 2005.

MIOTO, Regina Célia Tomaso. Família e políticas sociais. In: BOSCHETTI, Ivanete et al. (Orgs.). Políticas sociais no capitalismo: tendências contemporâneas. São Paulo: Cortez, 2008.

MIRZA, Christian. ¿Es posible un nuevo Estado de bienestar en América Latina? La reconfiguración de las matrices de bienestar en el MERCOSUR. Serie Avances de Investigación, n.36. Madrid, marzo 2010.

MUÑOZ de BUSTILLO, Rafael. Retos y restricciones del estado de bienestar en el cambio de siglo. En: . (Ed.). El estado de bienestar em el cambio de siglo. Madrid: Alianza, 2000.

NAVARRO, Vicenç. ¿Quién paga los costes del euro? Disponível em: <http:// www.vnavarro.org/wp-content/uploads/2010/02/quien-paga-los-costes-del-euro18feb10.pdf> Acesso em: setembro 2011. 
OFFE, Claus. Problemas estruturais do estado capitalista. Rio de Janeiro: Tempo Brasileiro. 1984.

OLSSON, Giovanni. Poder político e sociedade internacional contemporânea. Ijui, Unijuí, 2007.

PIERSON, Paul. Sobrellevando la austeridade permanente. Reestructuración del estado de bienestar en las democracias desarrolladas. Zona Abierta, 2006.

PIERSON, Paul. Dismantling the welfare state? Reagan, Thatcher and the politics of retrenchment. Cambridge: Cambridge University Press, 1994.

PIERSON, Paul. The new politics of the welfare State. World Politics, v.48, n.2, p.143-79, 1996.

PISARELLO. Gerardo. Los derechos sociales y sus garantias: elementos para uma reconstrucción. Madrid: Trotta, 2007.

. Un largo termidor. La ofensiva del constitucionalismo antidemocrático.

Madrid: Editorial Trotta, 2011.

RICHARD, Clayton; PONTUSSON, Jonas. El recorte del estado de bienestar reconsiderado: reducción de los derechos, restructuración del sector público y tendencias desigualitarias en las sociedades capitalistas avanzadas. Zona Abierta. v.114/115, p.121-164, 2006.

SCHMITTER, Philippe C. A experiência da integração europeia e seu potencial para a integração regional. Lua Nova, São Paulo, v.80, p.9-44, 2010.

SINGER, Paul. Cidadania para todos. In: PINSKY, Jaime; PINSKY, Carla Bassanezi (Org.). História da cidadania. São Paulo: Editora Contexto, 2003.

VACCA, Giuseppe. Por um novo reformismo. Rio de Janeiro: Contraponto, 2009.

VIGEVANI, Tullo; RAMAZINI JUNIOR, Haroldo. Mudanças da inserção brasileira na América Latina. Lua Nova, São Paulo, v.78, p.37-75, 2009.

WEBER, Max. Ciência e política, duas vocações. São Paulo: Cultrix, [200?].

ZOLO, Danilo. La justicia de los vencedores: de Nuremberg a Bagdad. Buenos Aires: Edhasa, 2007. 